\title{
CARBON DIOXIDE, HYDROGRAPHIC, AND CHEMICAL DATA OBTAINED DURING THE R/V METEOR CRUISE 18/1 IN THE NORTH ATLANTIC OCEAN \\ (WOCE SECTION A1E, SEPTEMBER 1991)
}

\section{Contributed by}

Kenneth M. Johnson*, Bernd Schneider*, Lutger Mintrop $^{* * *}$, and Douglas W. R. Wallace*,

*Brookhaven National Laboratory

Upton, New York, U.S.A.

*Institut für Ostseeforschung

Rostock-Warnemünde, Germany

*** Institut für Meereskunde

Kiel, Germany

Prepared by Alexander Kozyr ${ }^{* * * *}$

Carbon Dioxide Information Analysis Center

Oak Ridge National Laboratory

Oak Ridge, Tennessee, U.S.A.

****Energy, Environment, and Resources Center

The University of Tennessee, Knoxville, Tennessee, U.S.A.

Environmental Sciences Division

Publication No. 4543

Date Published: July 1996

Prepared for the

Global Change Research Program

Environmental Sciences Division

Office of Health and Environmental Research

U.S. Department of Energy

Budget Activity Numbers KP 0502000 and KP 0505000

Prepared by the

Carbon Dioxide Information Analysis Center

OAK RIDGE NATIONAL LABORATORY

Oak Ridge, Tennessee 37831-6335

managed by

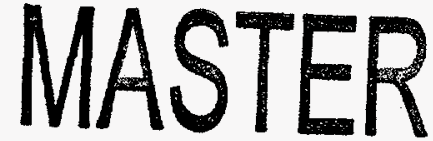

LOCKHEED MARTIN ENERGY RESEARCH CORP.

for the

U.S. DEPARTMENT OF ENERGY

under contract DE-AC05-96OR22464 



\section{DISCLAIMER}

This report was prepared as an account of work sponsored by an agency of the United States Government. Neither the United States Government nor any agency thereof, nor any of their employees, makes any warranty, express or implied, or assumes any legal liability or responsibility for the accuracy, completeness, or usefulness of any information, apparatus, product, or process disclosed, or represents that its use would not infringe privately owned rights. Reference herein to any specific commercial product, process, or service by trade name, trademark, manufacturer, or otherwise does not necessarily constitute or imply its endorsement, recommendation, or favoring by the United States Government or any agency thereof. The views and opinions of authors expressed herein do not necessarily state or reflect those of the United States Government or any agency thereof. 



\section{CONTENTS}

Page

LIST OF FIGURES $\ldots \ldots \ldots \ldots \ldots \ldots \ldots \ldots \ldots \ldots \ldots \ldots \ldots \ldots \ldots \ldots$

LIST OF TABLES $\ldots \ldots \ldots \ldots \ldots \ldots \ldots \ldots \ldots \ldots \ldots \ldots \ldots \ldots \ldots \ldots$

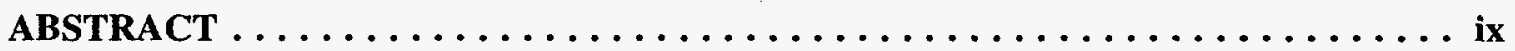

PART 1: OVERVIEW $\ldots \ldots \ldots \ldots \ldots \ldots \ldots \ldots \ldots \ldots \ldots \ldots \ldots \ldots$

1. BACKGROUND INFORMATION $\ldots \ldots \ldots \ldots \ldots \ldots \ldots \ldots \ldots$

2. DESCRIPTION OF THE RESEARCH VESSEL AND EXPEDITION $\ldots \ldots \ldots 4$

2.1 R/V Meteor: Technical Details and History ............... 4

2.2 Cruise Information $\ldots \ldots \ldots \ldots \ldots \ldots \ldots \ldots \ldots \ldots \ldots \ldots$

2.3 Cruise Summary $\ldots \ldots \ldots \ldots \ldots \ldots \ldots \ldots \ldots \ldots \ldots \ldots$

3. DESCRIPTION OF VARIABLES AND METHODS $\ldots \ldots \ldots \ldots \ldots \ldots \ldots$

4. DATA CHECKS AND PROCESSING PERFORMED BY CDIAC $\ldots \ldots \ldots \ldots$

5. HOW TO OBTAIN THE DATA AND DOCUMENTATION $\ldots \ldots \ldots \ldots$

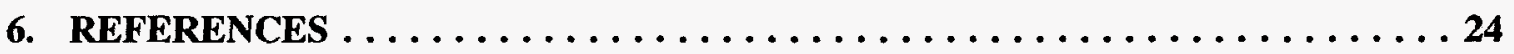

PART 2: CONTENT AND FORMAT OF DATA FILES $\ldots \ldots \ldots \ldots \ldots \ldots \ldots$

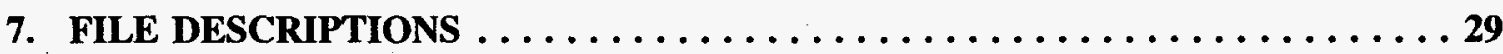

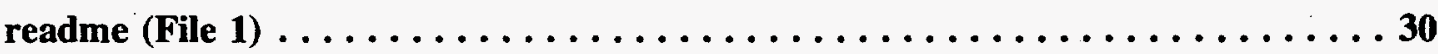

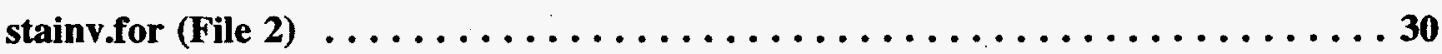

met18dat.for (File 3) $\ldots \ldots \ldots \ldots \ldots \ldots \ldots \ldots \ldots \ldots \ldots \ldots \ldots \ldots \ldots \ldots \ldots$

uwpco2.for (File 4) $\ldots \ldots \ldots \ldots \ldots \ldots \ldots \ldots \ldots \ldots \ldots \ldots \ldots \ldots \ldots \ldots \ldots \ldots$

met18sta.inv (File 5) $\ldots \ldots \ldots \ldots \ldots \ldots \ldots \ldots \ldots \ldots \ldots \ldots \ldots \ldots \ldots \ldots$ 


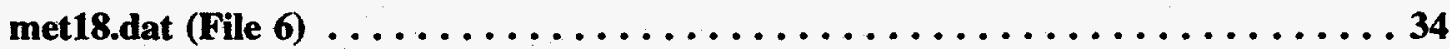

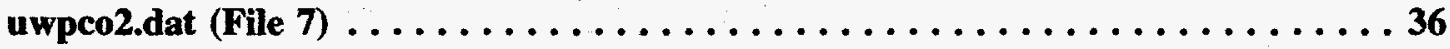

8. VERIFICATION OF DATA TRANSPORT $\ldots \ldots \ldots \ldots \ldots \ldots \ldots \ldots \ldots \ldots$

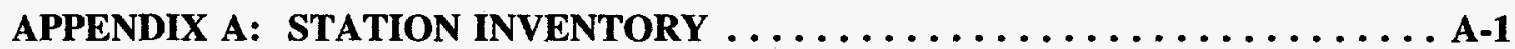




\section{LIST OF FIGURES}

Figure

Page

1 Station locations during R/N Meteor Cruise 18/1 (WOCE Section AlE) ...... 4

2 Sampling depths at all hydrographic stations occupied during R/V Meteor

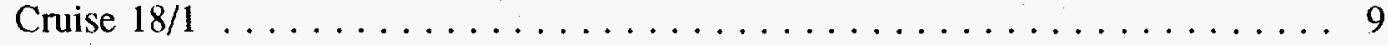

3 Plot of the differences between the measured and certified $\mathrm{TCO}_{2}$ values for SOMMA-Coulometer Systems I and II during Cruise 18/1 aboard the $\mathrm{R} / \mathrm{V}$ Meteor . . . . . . . . . . . . . . . . . . . . . . . . 13

4 Track of underway $\mathrm{pCO}_{2}$ measurements made during $\mathrm{R} / \mathrm{V}$ Meteor Cruise $18 / 1 \ldots 17$

5 Data plots of underway sea surface salinity, temperature, and $\mathrm{pCO}_{2}$ measured

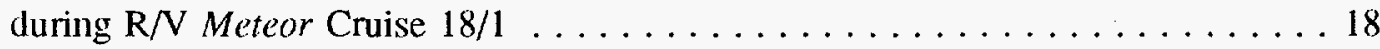

6 Nested profiles: Total carbon $(\mu \mathrm{mol} / \mathrm{kg})$ vs pressure $(\mathrm{dbar}) \ldots \ldots \ldots \ldots \ldots$

$7 \quad$ Nested profiles: Total alkalinity $(\mu \mathrm{mol} / \mathrm{kg})$ vs pressure $(\mathrm{dbar}) \ldots \ldots \ldots \ldots \ldots$

8 Property-property plots for all stations occupied during R/V Meteor

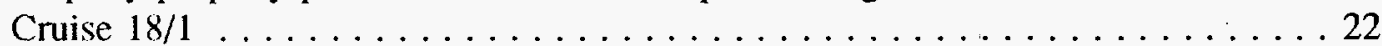





\section{LIST OF TABLES}

Table

Page

1 Summary of $\mathrm{CRM} \mathrm{TCO}_{2}$ analyses made aboard the R/V Meteor during Cruise 18/1 (September 1991) with two SOMMA-Coulometer Systems (BNL I and BNL II)

2 Summary of sample precision for $\mathrm{TCO}_{2}$ analyses made aboard the R/V Meteor during Cruise 18/1 September 4-15, 1991 with two SOMMA-Coulometer Systems (BNL I and BNL II)

3 Summary of $\mathrm{TCO}_{2}$ analyses for "between sample" duplicates, for which one of the duplicates was analyzed on SOMMA-Coulometer System BNL I and the other was analyzed on BNL II aboard the R/V Meteor during Cruise 18/1

4 Comparison of shipboard analyses of $\mathrm{TCO}_{2}$ by coulometry (BNL) during the $\mathrm{R} / \mathrm{V}$ Meteor Cruise 18/1 and the shore-based reference analyses of $\mathrm{TCO}_{2}$ by manometry on duplicate samples in the laboratory of C. D. Keeling at SIO

5 Content, size, and format of data files

6 Partial listing of "met18sta.inv" (File 5 ) $\ldots \ldots \ldots \ldots \ldots \ldots \ldots \ldots \ldots \ldots \ldots \ldots$

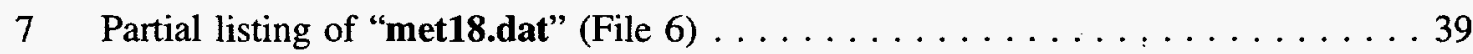

8 Partial listing of "uwpco2.dat" (File 7) $\ldots \ldots \ldots \ldots \ldots \ldots \ldots \ldots$

A.1 Station inventory information for the 61 sites occupied during R/V Meteor Cruise 18/1 A-4 



\section{ABSTRACT}

Johnson, K. M., B. Schneider, L. Mintrop, and D. W. R. Wallace. 1996. Carbon Dioxide, Hydrographic, and Chemical Data Obtained During the R/V Meteor Cruise 18/1 in the North Atlantic Ocean (WOCE Section A1E, September 1991). ORNL/CDIAC-91, NDP-056. Carbon Dioxide Information Analysis Center, Oak Ridge National Laboratory, Oak Ridge, Tennessee. $53 \mathrm{pp}$.

The North Atlantic Ocean is characterized by an intense meridional circulation cell carrying near-surface waters of tropical and subtropical origin northward and deep waters of arctic and subarctic origin southward. The related "overturning" is driven by the sinking of water masses at high latitudes. The overturning rate and thus the intensity of the meridional transports of mass, heat, and salt, is an important control parameter for the modeling of the ocean's role in climate. Certainly such estimates require more than one survey of the study area; therefore, the Research Vessel (R/V) Meteor Cruise 18/1 was one in a series of cruises in the North Atlantic that started in March 1991 and continued until 1995 (Meincke 1993).

This data documentation discusses the procedures and methods used to measure total carbon dioxide $\left(\mathrm{TCO}_{2}\right)$ and total alkalinity (TALK) at hydrographic stations, as well as underway partial pressure of $\mathrm{CO}_{2}\left(\mathrm{pCO}_{2}\right)$ measured during the $\mathrm{R} / \mathrm{V}$ Meteor Cruise 18/1 in the North Atlantic Ocean (Section A1E). Conducted as part of the World Ocean Circulation Experiment (WOCE) and the German North Atlantic Overturning Rate Determination expedition, the cruise began in Reykjavik, Iceland, on September 2, 1991, and ended after 24 days at sea in Hamburg, Germany, on September 25, 1991. WOCE Zonal Section A1E began at $60^{\circ} \mathrm{N}$ and $42^{\circ} 30^{\prime} \mathrm{W}$ (southeast of Greenland) and continued southeast with a closely spaced series of hydrocasts to $52^{\circ} 20^{\prime} \mathrm{N}$ and $14^{\circ} 15^{\prime} \mathrm{W}$ (Porcupine Shelves). Measurements made along WOCE Section A1E included pressure, temperature, salinity, and oxygen measured by a conductivity, temperature and depth (CTD) sensor; bottle salinity; oxygen; phosphate; nitrate; nitrite; silicate; $\mathrm{TCO}_{2}$; TALK; and underway $\mathrm{pCO}_{2}$. A total of 61 CTD casts were made, including 59 bottle casts and 2 calibration stations. Replicate samples from seven Niskin bottles at five stations were also collected for later shorebased reference analyses of $\mathrm{TCO}_{2}$ by vacuum extraction and manometry and TALK in the laboratory of Dr. Charles D. Keeling, Scripps Institution of Oceanography; these results are also included in this report.

$\mathrm{TCO}_{2}$ was measured by using an automated sample processor, to extract $\mathrm{CO}_{2}$ from seawater samples, coupled to a coulometer, to detect the extracted gas. The precision and accuracy of the system was $\pm 1.60 \mu \mathrm{mol} / \mathrm{kg}$. Samples collected for TALK were measured using standard potentiometric techniques; precision was $\pm 2.0 \mu \mathrm{mol} / \mathrm{kg}$. Underway $\mathrm{pCO}_{2}$ was measured by infrared photometry; precision was $\pm 2 \mu$ atm.

The R/V Meteor Cruise 18/1 data set is available free of charge as a numeric data package (NDP) from the Carbon Dioxide Information Analysis Center. The NDP consists of three oceanographic data files, three FORTRAN 77 data retrieval routine files, a readme file, and this printed documentation, which describes the contents and format of all files as well as the procedures and methods used to obtain the data.

Keywords: carbon dioxide; alkalinity, $\mathrm{pCO}_{2}$, World Ocean Circulation Experiment; North Atlantic Ocean; hydrographic measurements; carbon cycle 

PART 1:

OVERVIEW 


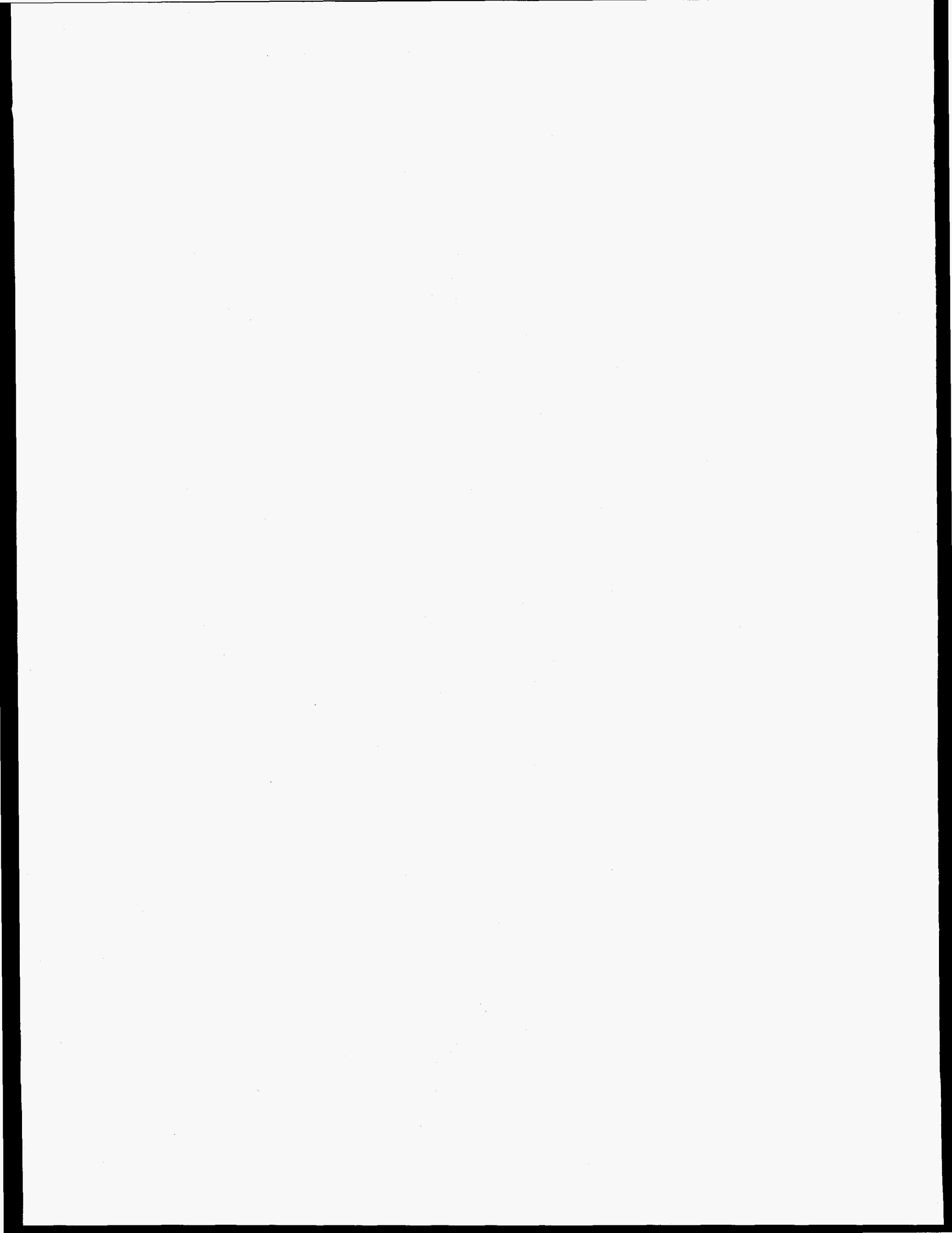

$$
2
$$




\section{BACKGROUND INFORMATION}

To better understand the ocean's role in climate and climatic changes, several large experiments have been conducted in the past, and others are currently under way. The World Ocean Circulation Experiment (WOCE) is a major component of the World Climate Research Program. Although total carbon dioxide $\left(\mathrm{TCO}_{2}\right)$ is not an official WOCE measurement, a coordinated effort, supported in the United States by the U.S. Department of Energy (DOE) and the National Oceanic and Atmospheric Administration, is being made on WOCE cruises to measure the global, spatial, and temporal distributions of $\mathrm{TCO}_{2}$ and other carbon-related parameters. The $\mathrm{CO}_{2}$ survey goals include estimation of the meridional transport of inorganic carbon in a manner analogous to the oceanic heat transport (Bryden and Hall 1980; Brewer et al. 1989; Roemmich and Wunsch 1985), evaluation of the exchange of $\mathrm{CO}_{2}$ between the atmosphere and the ocean, and preparation of a database suitable for both carbon-cycle modeling and the subsequent assessment of the anthropogenic $\mathrm{CO}_{2}$ increase in the oceans. The final data set is expected to cover $\sim 23,000$ stations in the Atlantic, Pacific, and Indian oceans.

The Research Vessel (R/V) Meteor Cruise 18/1, from Reykjavik, Iceland, to Hamburg, Germany, from September 2 to 25, 1991, completed WOCE Zonal Section A1E (Fig. 1). It was one of a series of cruises starting in 1991 that are contributing to the WOCE North Atlantic Overturning Rate Determination (WOCE-NORD) program. The WOCE-NORD program is coordinated jointly by the Bundesamt für Seeschiffahrt und Hydrographie (Hamburg) and the Institut für Meereskunde (Hamburg). The sampling strategy of WOCE-NORD is to combine seasonally repeated hydrographic sections between southern Greenland and Iceland with current measurements from moored arrays. Program objectives include the direct determination of the overturning rates and the intensity of the meridional transports of mass, heat, and salt. Section A1E was chosen to be south of the major wintertime convection regions so as to avoid both water mass formation processes and shallow topography, either of which could cause difficulties in calculating volume transports.

This document describes the cooperative efforts of chemical oceanographers from Brookhaven National Laboratory (BNL) and the Institut für Meereskunde Kiel (IFMK) to make high-quality $\mathrm{CO}_{2}$ measurements along the WOCE Section A1E. 


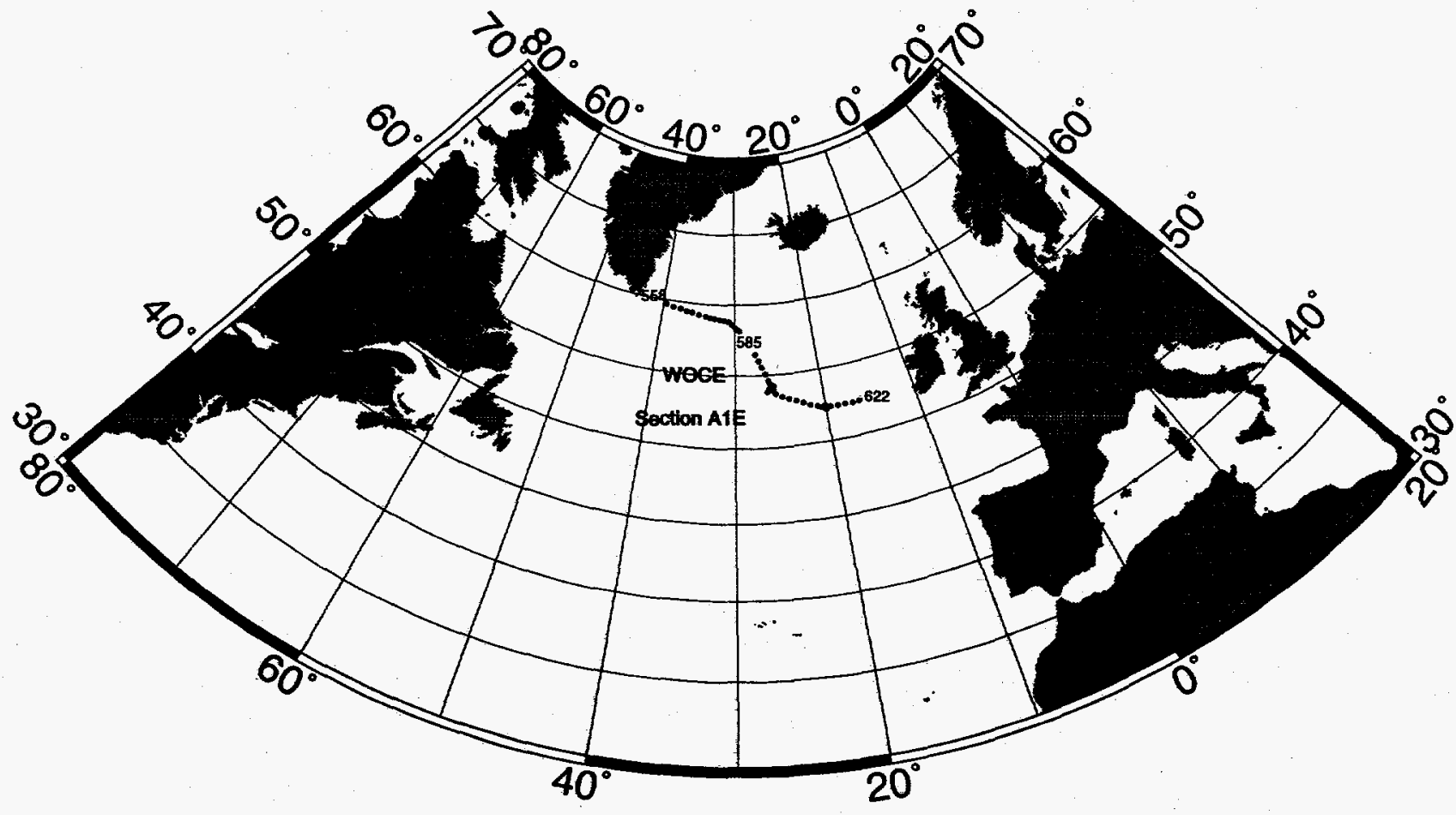

Figure 1. Station locations during R/V Meteor Cruise 18/1 (WOCE Section A1E).

\section{DESCRIPTION OF THE RESEARCH VESSEL AND EXPEDITION}

\subsection{R/V Meteor: Technical Details and History}

The R/V Meteor is owned by the Federal Republic of Germany's Ministry of Research and Technology (BMFT), which financed its construction. It is operated by the German Research Foundation (DFG), which provides about $70 \%$ of its operating funds while BMFT supplies the remainder. DFG also plans the scientific cruises and appoints the chief scientists. The Operations Control Office of the University of Hamburg is responsible for management, logistics, execution, and supervision of ship operations. These functions are performed through cooperation with expedition coordinators and the managing owners, the Reedereigemeinschaft Forschungsschiffahrt $\mathrm{GmbH}$, located in Bremen, Germany. The latter is responsible for hiring, provisioning, and coordinating ship maintenance. Used for ocean research primarily in the Atlantic and Indian Oceans, the R/V Meteor routinely carries scientists from many different countries. Construction 
of the Meteor was completed in 1986 in Travemunde, Germany. The basic features of the vessel are as follows:

Port of registration
Call sign
Classification
Operator
Built
Basic dimensions:
$\quad$ Gross registered tonnage
Net registered tonnage
Displacement
Overall length
$\quad$ Beam
$\quad$ Draught max.
$\quad$ Service speed
$\quad$ Depth main deck
Personnel
Main engine
Propulsion
Fuel consumption
Maximum cruise duration
Nautical equipment

Science quarters

\author{
Hamburg \\ DBBH \\ GL+100A4E2+MC Auto \\ Institut für Meereskunde, Universität Hamburg \\ 1985-1986 at Schlichting Werft, Travemunde, West Germany
}

3990

1284

$4780 \mathrm{t}$

$97.50 \mathrm{~m}$

$16.50 \mathrm{~m}$

$5.60 \mathrm{~m}$

$12 \mathrm{kn}$

$7.70 \mathrm{~m}$

Crew: 32; scientists: 30

$4 \times$ Mak6M $322=4 \times 1000 \mathrm{~kW}$ at $750 \mathrm{rpm}$

Diesel-electrical, tandem-motor $=2 \times 1150 \mathrm{~kW}$

$\sim 12.0 \mathrm{t}$ IFO-80 per day at service speed

60 days

Integrated navigation system with data transfer to position computer, echosounder synchronization and supervision, and data-processing facility

20 laboratories on the main deck with $\sim 400 \mathrm{~m}^{2}$ of working space for multidisciplinary research

R/V Meteor (I) was constructed in 1925, the first research and survey vessel of that name. Owned by the German navy, it was based in Wilhelmshaven. One of its first expeditions was the German Atlantic Ocean Expedition of 1925-27, which was organized by the Institute of Marine Research in Berlin. Thereafter, the vessel was used for German physical, chemical, and microbiological marine investigations and for German navy surveying and fisheries protection duties.

R/V Meteor (II) was planned after the 1950s; it was operated by the Deutsche Forschungsgemeinschaft (German Science Community) in Bad Godesberg and by the Deutsches Hydrographisches Institut (German Hydrographic Institute) in Hamburg. Commissioned in 1964, $\mathrm{R} / \mathrm{V}$ Meteor (II) participated in the International Indian Ocean Expedition.

Multipurpose R/V Meteor (III), used on the cruise described in this documentation, was completed in 1986 and replaced R/V Meteor (II). Based in Hamburg, it is used for German ocean research worldwide and for cooperative efforts with other nations researching in this field. The vessel serves scientists of all marine disciplines in all of the world's oceans.

\subsection{Cruise Information}

Information about the $\mathrm{R} / \mathrm{V}$ Meteor $18 / 1$ cruise is summarized as follows: 


$\begin{array}{ll}\text { Ship name } & \text { Meteor } \\ \text { Cruise/leg } & 18 / 1 \\ \text { Ports of call } & \text { Reykjavik, Iceland to Hamburg, Germany } \\ \text { Dates } & \text { September 2-25, 1991 } \\ \text { Funding support } & \text { German Science Community; } \\ & \text { Federal Ministry of Research and Technology, Bonn, Germany; and } \\ \text { Chief Scientist } & \begin{array}{l}\text { U.S. Department of Energy (DOE) } \\ \text { Professor Dr. Jens Meincke, Institut für Meereskunde, Universität }\end{array} \\ \text { Master } & \text { Hamburg, Germany } \\ & \text { Heinrich Bruns }\end{array}$

Parameters measured

CTD, Salinity, XBT

Nutrients

Oxygen

CFCs

Tritium, $\mathrm{He},{ }^{14} \mathrm{C}$

$\mathrm{TCO}_{2}$

Underway $\mathrm{pCO}_{2}$

Total alkalinity (TALK)

ADCP

Rain gauges

Participating Institutions

BNL

BSH

IFMH

IFMK

IUPH

SIO

UBP

\section{Institution}

BSH

SIO

SIO

UBP

IUPH

BNL, IFMK

IFMK

IFMK

IFMH

IFMK

\section{Principal investigators}

A. Sy

J. Swift, D. Bos, D. Muus

J. Swift, D. Bos, D. Muus

W. Roether, A. Putzka

R. Bayer

K. Johnson, B. Schneider,

A. Morak, R. Ramirez

B. Schneider

L. Mintrop, A. Korves

M. Bersch, J. Meincke

H.-J. Isemer

\subsection{Cruise Summary}

The BNL $\mathrm{CO}_{2}$ group, consisting of K. M. Johnson and R. Ramirez, arrived in Reykjavik, Iceland, on August 29 and went aboard the next day to join the IFMK $\mathrm{CO}_{2}$ group members, Drs. Bernd Schneider and Lutger Mintrop. Dr. Jens Meincke was already aboard as Chief Scientist. Setting up of the equipment began on August 30 and was completed on the morning of September 2. The R/V Meteor departed Reykjavik at 11 a.m. on September 2, 1991. The ship immediately encountered rough weather conditions with gale force winds. Two test stations were completed during the transit across the Denmark Strait to the first station (no. 558) on the South-East Greenland shelf, which was reached on September 5. The earlier gale force winds were replaced by a quiet period characterized by humid air masses over cold water, which resulted in fog. The hydrocast routine was interrupted by winch and rosette bottle-release problems on September 6 
and 7 and by currentmeter deployments on September $9,10,11,14$, and 19. Bad weather forced several delays on September 13, when the pressure dropped to $980 \mathrm{hPa}$, wind gusted to 11 Beaufort, and waves rose to $8 \mathrm{~m}$. This scenario was repeated on September 17, and the slowly receding sea conditions thereafter continued to plague the oceanographic work until the end of the hydrographic program of WOCE section A1E at station 622 on September 21. Each rough period was followed by reduced sampling on stations ( 12 bottles instead of 24 on each rosette), but these stations were restricted to short lines perpendicular to the WOCE line. The station locations are shown in Fig. 1. Of the six stations $(592,593,595,606,607$, and 608) taken normal to the WOCE line, only station 607 was sampled for carbonate system parameters. XBT measurements were made at selected CTD stations in parallel with the CTD casts, and acoustic Doppler current profiles (ADCP) were made continuously from September 2 to September 22 to measure the instantaneous near-surface currents.

Two single-operator multiparameter metabolic analyzers (SOMMAs) from BNL (hereafter the systems are designated BNL I and BNL II), one potentiometric alkalinity titrator from IFMK and one ifrared-based system for underway $\mathrm{pCO}_{2}$ measurements from IFMK, were on board for this cruise. A total of $583 \mathrm{TCO}_{2}$ samples, normally collected in conjunction with tracer samples, were taken from 31 section stations, 1 test station (no. 557) and two calibration stations (nos. 581, 608 ) from a total of 59 bottle casts. Not all 59 stations could be sampled for tracers and $\mathrm{TCO}_{2}$ because of the limited time available for analysis. The standard WOCE parameters (oxygen, nutrients, and salinity) were sampled on all stations, and on approximately every other station these were augmented by the tracer samples for CFCs, carbonate, helium, tritium, and radiocarbon as the ship steamed eastward from the southeastern tip of Greenland to the coast of Ireland. The density of the $\mathrm{CO}_{2}$ sampling was fairly constant, $\sim 2$ stations per day; the underway $\mathrm{pCO}_{2}$ system operated continuously.

Both electrical and mechanical problems were noted for each of the SOMMA coulometer systems. BNL II was most severely affected and was declared nonoperational on September 16, when the magnetic valves on the SOMMA chassis could no longer be operated reliably, the electronic calibration factor suddenly changed by $+0.11 \%$ (a factor of 10 higher than the usual precision of $\pm 0.01 \%$ ), and the communication between the keyboard and PC became erratic. The final Certified Reference Material (CRM) run on this date was $6 \mu \mathrm{mol} / \mathrm{kg}$ lower than the certified value, and test sample duplication was equally poor. When this system was operated several months later in the laboratory, all components functioned satisfactorily, and it was impossible to determine the cause of the shipboard difficulties. BNL I experienced two serious problems. First, the BNL I coulometer became inoperable when the photodetector amplifier failed on September 7. Fortunately, a backup coulometer from Kiel was available, and it was immediately placed in service. Second, the gas calibration system apparently failed on September 10 as a result of cross-talk between the gas sample loops $\left(\mathrm{CO}_{2}\right.$ leaking from one loop into the other through a surface scratch or scoring of the valve, which contaminates the carrier gas). This manifested itself as a very noisy system with a very high and unusable blank. The problem was corrected by disconnecting the gas sample valve from the system so that the carrier gas $\left(\mathrm{N}_{2}\right)$ passed directly from the gas cylinder into the SOMMA stripper.

Because of the rough weather, plans for a return voyage around the north of Scotland to Hamburg were changed, and the ship arrived in Hamburg on September 25, via the English Channel, where winds astern arising from a low pressure system near the Faeroe Islands hastened the return voyage. 


\section{DESCRIPTION OF VARIABLES AND METHODS}

The data file met18.dat (see descriptions of data files in Part 2) in this numeric data package (NDP) contains the following variables: station numbers; cast numbers; sample numbers; bottle numbers; CTD pressures, temperatures, and salinities; reversing thermometer readings; potential temperatures; bottle salinities; concentrations of dissolved oxygen, silicate, nitrate, nitrite, and phosphate; $\mathrm{TCO}_{2}$ and TALK concentrations; and quality flags. The station inventory file m18sta.inv contains expedition codes, section numbers, station numbers, cast numbers, sampling dates (i.e., month, day, year), sampling times, latitude, longitude, and bottom depth for each station. The data file uwpco2.dat contains sampling dates (i.e., day, month, year), sampling times, latitude, longitude, sea surface salinity, sea surface temperature, and underway $\mathrm{pCO}_{2}$ measurements.

Water samples were collected in 24 General Oceanics 10-L Niskin bottles mounted on a Neil Brown Mark III CTD instrument (S/N NB3) provided by IFMK. Data were acquired at a rate of $32 \mathrm{~ms} / \mathrm{cycle}$ by using Oceansoft Rev. 3.1. Further details are given by Meincke (1993), and additional data concerning postcruise and precruise laboratory calibrations of the CTD temperature, pressure, conductivity, and oxygen sensors may be found in Siedler and Zenk (1992) and Ruhsam (1994). ADCP measurements to a depth of $300 \mathrm{~m}$ were made nearly continuously (with some breaks for rough weather and minor computer malfunctions) from September 2 to 22 with a hull-mounted system from RD Instruments (San Diego) that used a pulse frequency of $150 \mathrm{kHz}$.

The rosette systems used with the CTD on this cruise experienced various mechanical and electrical problems such that tripping failures were not uncommon--especially at stations 596-613. Repeated checks on board and several careful verifications with the complete bottle data sets were carried out, and the current pressures for each sample are considered correct by the responsible personnel. Reversing thermometers, both electronic (SIS, Kiel) and mechanical (Gohla Precision, Kiel), were also read at the completion of each cast. The processing and quality control of CTD and bottle data performed at BSH followed the guidelines published in the WOCE Operations Manual (WHPO 91-1, 1991). Salinity corrections were made by using bottle salinities measured 1-2 days after collection and determined on a Guildline Autosal model 8400A, which was standardized at each station with reference water (batch P112). Because of temporal conductivity sensor shifts, separate corrections were applied for stations 558-566, 567-602, and 603-622. The final salinity data are expected to be accurate to \pm 0.002 on the Practical Salinity Scale (PSS). Bottle oxygen was determined by Winkler titration following the techniques of Carpenter (1965) and Culberson and Will (1991), by using standards and blanks run in seawater. Subsequently, all Winkler results were recalculated and verified by staff of Oceanographic Data Facility at SIO. The concentrations of nitrate, nitrite, phosphate, and silicate dissolved in seawater were determined for samples collected in high-density polyethylene screw-capped bottles by using a Technicon Autoanalyzer according to procedures given in Hager et al. (1972) and Atlas et al. (1971) and by using the spectrophotometric methods of Armstrong et al. (1967) and Bernhardt and Wilhelms (1967). The analyses were completed within $24 \mathrm{~h}$ of sampling, including storage at $6^{\circ} \mathrm{C}$ for no more than $15 \mathrm{~h}$. Preweighed standards were used to prepare the working standards on board ship.

The $\mathrm{TCO}_{2}$ concentration was determined by using two SOMMAs described and designed by K. M. Johnson and coworkers (Johnson et al. 1985, 1987; Johnson and Wallace 1992). Along with 158 duplicates, 583 individual samples (total analyzed $=741$ ) from 33 stations (Fig. 2) were collected in $300-\mathrm{mL}$, precombusted $\left(450^{\circ} \mathrm{C}\right.$ for $24 \mathrm{~h}$ ) BOD bottles and immediately poisoned with $\mathrm{HgCl}_{2}$, according to DOE's Handbook of Methods for the Analysis of the Various Parameters of the Carbon Dioxide System in Sea Water (DOE 1994). Before analysis the BOD bottles were kept 


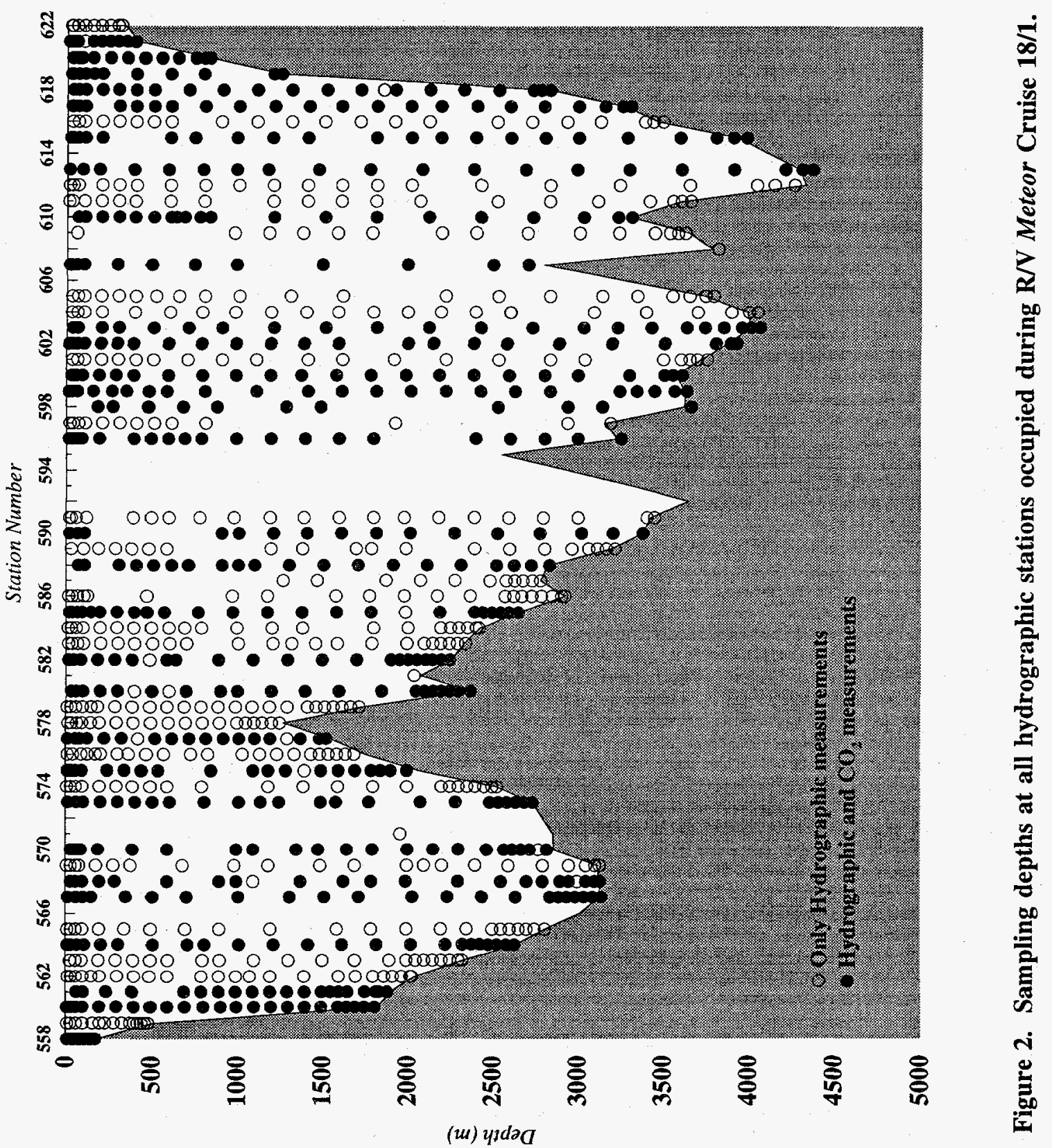


in darkness in a cold room until thermally equilibrated to the analytical temperature. Dr. Andrew Dickson of SIO supplied 61 CRMs (DOE 1994), which were also analyzed (37 on BNL I and 24 on BNL II). The CRMs were from Batch 7 (B7), which was a filtered sterile salt solution ( $\mathrm{S}=$ 37.12) spiked with $\mathrm{Na}_{2} \mathrm{CO}_{3}$, and analyzed for $\mathrm{TCO}_{2}$ by vacuum extraction and manometry in the laboratory of C. D. Keeling at SIO. The certified $\mathrm{TCO}_{2}$ value was $1926.41 \pm 0.82 \mu \mathrm{mol} / \mathrm{kg}(\mathrm{n}=$ 13).

Seawater introduced from an automated "to deliver" pipette into a stripping chamber was acidified, and the resultant $\mathrm{CO}_{2}$, after drying, was coulometrically titrated on a model $5011 \mathrm{UIC}$ coulometer. In the coulometer cell, the hydroxyethylcarbamic acid that formed from the reaction of $\mathrm{CO}_{2}$ and ethanolamine was titrated coulometrically (electrolytic generation of $\mathrm{OH}^{-}$) with photometric end point detection. The product of the time and the current passed through the cell during the titration was related by Faraday's Constant to the number of moles of $\mathrm{OH}^{-}$generated and thus to the moles of $\mathrm{CO}_{2}$ that reacted with ethanolamine to form the acid. When possible (see text below) the SOMMA-coulometer systems were calibrated with pure $\mathrm{CO}_{2}$ through the use of hardware consisting of an eight-port gas sampling Valve (GSV) with two sample loops connected to a source of pure $\mathrm{CO}_{2}$ through an isolation valve with the vent side of the GSV plumbed to a barometer. When a gas loop was filled with $\mathrm{CO}_{2}$, the mass (moles) of $\mathrm{CO}_{2}$ contained therein was calculated by dividing the loop volume $(V)$ by the Molar Volume of $\mathrm{CO}_{2}$ at ambient $(T)$ and $(P)$. The molar volume of $\mathrm{CO}_{2}\left[V\left(\mathrm{CO}_{2}\right)\right]$ was calculated iteratively from an expression using the instantaneous barometric pressure $(P)$, loop temperature $(T)$, gas constant $(\mathrm{R})$, and the first virial coefficient $\mathrm{B}(T)$ for pure $\mathrm{CO}_{2}$ :

$$
V\left(\mathrm{CO}_{2}\right)=\mathrm{RT} / P\left[1+\mathrm{B}(\mathrm{T}) / V\left(\mathrm{CO}_{2}\right)\right] \text {. }
$$

The ratio of the calculated mass to the mass determined coulometrically was the gas calibration factor (CALFAC) used to correct the subsequent titrations for small departures from $100 \%$ theoretical response (DOE 1994). The volume of the loops was determined gravimetrically with deionized water by the method of Wilke et al. (1993). When possible (see text below) the standard operating procedure was to make gas calibrations daily or for each new titration cell used (normally one cell per day).

Before the cruise, the "to deliver" volume (TDV) of the SOMMA sample pipette was determined (calibrated) gravimetrically at $20^{\circ} \mathrm{C}$ with milli- $\mathrm{Q}$ deionized water, which had been degassed with Helium. The thermostatted sample pipette was filled with water at the same temperature, and then discharged into preweighed $50-\mathrm{mL}$ serum bottles which were reweighed on a model R300S (Sartorius, Göttingen, Germany) balance. The apparent weight (g) of water collected $\left(W_{\text {air }}\right)$ was corrected to the mass in vacuo $\left(M_{\mathrm{vac}}\right)$ from the following equation:

$$
M_{\mathrm{vac}}=W_{\mathrm{air}}+W_{\mathrm{air}}(0.0012 / d-0.0012 / 8.0),
$$

where 0.0012 is the sea level density of air at $1 \mathrm{~atm}, d$ is the density of the calibration fluid at the pipette temperature and sample salinity, and 8.0 is the density of the stainless steel weights. TDV was calculated by using the following equation:

$$
\mathrm{TDV}=M_{\mathrm{vad}} / d .
$$

This procedure was repeated at sea, except the serum bottles were crimp-sealed and reweighed on shore within 3 weeks of collection. The precruise TDV of the pipette for system 
BNL I was $28.7108 \mathrm{~mL}$ at $20^{\circ} \mathrm{C}$. During the cruise the pipette temperature was kept at $\sim 10.2^{\circ} \mathrm{C} \pm 0.3^{\circ} \mathrm{C}$. The calculated TDV at $10.2^{\circ} \mathrm{C}\left(\mathrm{TDV}_{\mathrm{T} 2}\right)$ was $28.7080 \mathrm{~mL}$ :

$$
\operatorname{TDV}_{\mathrm{T} 2}=\operatorname{TDV}_{\mathrm{T} 1}\left[1+\mathrm{a}_{\mathrm{v}}\left(T_{2}-T_{1}\right)\right]
$$

where $\mathrm{a}_{\mathrm{v}}$ is the coefficient of volumetric expansion for pyrex-type glass $\left(1 \times 10^{-5 \circ} \mathrm{C}^{-1}\right), T_{2}$ is the measurement temperature, and $T_{1}$ is the calibration temperature. The corresponding results for the BNL II pipette were 29.6954 and $29.6925 \mathrm{~mL}$, respectively. During the cruise, eight TDV samples were collected at $10.2^{\circ} \mathrm{C}$ from the $\mathrm{BNL}$ I pipette and sealed for reweighing. The TDV from these weighings was $28.6845 \pm 0.0058 \mathrm{~mL}(0.02 \%)$, which differed from the calculated TDV of $28.7080 \mathrm{~mL}$ by $-0.0235 \mathrm{~mL}$, or $-0.082 \%$. For the BNL II pipette, 11 samples were taken at $10.2^{\circ} \mathrm{C}$ which gave a TDV of the $29.6712 \pm 0.0065 \mathrm{~mL}(0.02 \%)$, which differed from the calculated TDV of $29.6925 \mathrm{~mL}$ by $-0.0213 \mathrm{~mL}$, or $-0.072 \%$. Because the original laboratory calibration took place at $20^{\circ} \mathrm{C}$, and all of the analytical work aboard ship was done at $10.2^{\circ} \mathrm{C} \pm$ $0.3^{\circ} \mathrm{C}$ we have used the latter (shipboard) results for TDV to calculate the $\mathrm{TCO}_{2}$ values (i.e., for $\mathrm{BNL}$, TDV $=28.6845 \mathrm{~mL}$ at $10.2^{\circ} \mathrm{C}$; for $\mathrm{BNL}$ II, TDV $=29.6712 \mathrm{~mL}$ at $10.2^{\circ} \mathrm{C}$ ). These data support the current practice of ensuring identical calibration and analytical temperatures because it appeared that theoretical correction for glass expansion was not adequate to describe the TDV at temperatures significantly different from the calibration temperature (see also DOE 1994).

An IBM-compatible personal computer with two RS232 serial ports, one 24-line digital input/output port, and one analog-to-digital port was used to control the coulometer, barometer, solid state control relays, and temperature sensors, respectively. The temperature sensors (model LM34CH, National Semiconductor, Santa Clara, California), with a voltage output of $10 \mathrm{mV} /{ }^{\circ} \mathrm{F}$ built into the SOMMA, were calibrated against thermistors certified to $0.01^{\circ} \mathrm{C}$ (PN CSP60BT103M, Thermometrics, Edison, New Jersey) by using a certified mercury thermometer as a secondary standard. These sensors monitored the pipette, gas sample loop, and the coulometer cell temperatures. The barometer, model 216B-101 Digiquartz Transducer (Paroscientific, Inc., Redmond, Washington), was factory-calibrated for pressures between 11.5 and 16.0 psia. The SOMMA software was written in GWBASIC Version 3.20 (Microsoft Corp., Redmond, Washington), and the instrument was driven from the computer.

The analytical method for determination of $\mathrm{TCO}_{2}$ concentration in seawater used during R/V Meteor Cruise 18/1 differed from the technique described in an earlier data report (Johnson et al. 1995) for R/V Meteor Cruise 15/3 (March 1991). During Cruise 18/1 an electronic calibration procedure was used to check the theoretical response of the coulometers's voltage to frequency converter (VFC) as described in Johnson et al. (1993) and DOE (1994). At least two levels of current (usually 50 and $2 \mathrm{~mA}$ ) were passed through an independent and very precisely known resistance $(R)$ for a fixed time. The voltage $(V)$ across the resistance was continuously measured, and the instantaneous current $(I)$ across the resistance was calculated from Ohm's law and integrated over the calibration time. Then the number of pulses (counts) accumulated by the VFC during this time was compared with the theoretical number computed from the factory calibration of the VFC [frequency $=10^{5}$ pulses (counts) generated per second at $200 \mathrm{~mA}$ ] and the measured current. If the VFC was perfectly calibrated, electronic calibration yielded a straight line passing through the origin (intercept $=0$ ) with a slope of 1 . Calibrations and titrations were done with the coulometer in the counts mode (the total charge passed during a titration was displayed as the number of counts accumulated by the VFC). From the factory calibration of the VFC and the value of the Faraday (96489 Coulomb/mol), a scaling factor of $4.82445 \times 10^{3}$ counts $/ \mu \mathrm{mol}$ was derived, and the theoretical number micromoles of carbon titrated $(M)$ was determined by the following equation: 


$$
M=\left[\text { counts/4824.45 }-\left(\text { Blank } \times T_{\mathrm{T}}\right)-\left(I N T_{e c} \times I_{\mathrm{T}}\right)\right] / S L O P E_{e c}
$$

where $T_{\mathrm{T}}$ is the length of the titration in minutes, Blank is the system blank in $\mu \mathrm{mol} / \mathrm{min}, I N T_{e c}$ is the intercept from electronic calibration in $\mu \mathrm{mol} / \mathrm{min}, I_{\mathrm{T}}$ the time of continuous current flow in minutes, and $S L O P E_{e c}$ is the slope from electronic calibration. Note that the slope obtained from the electronic calibration procedure applied for the entire length of the titration, but the intercept applied only for the period of continuous current flow (usually 3-4 min). The $\mathrm{TCO}_{2}$ concentration in $\mu \mathrm{mol} / \mathrm{kg}$ was calculated with the following equation:

$$
C_{\mathrm{T}}=M \times \text { CALFAC } \times\left[1 /\left(\mathrm{TDV}_{\mathrm{T}} \times \rho\right)\right] \times 1.00017,
$$

where $C_{\mathrm{T}}$ is the $\mathrm{TCO}_{2}$, CALFAC is the gas calibration factor, $\mathrm{TDV}_{\mathrm{T}}$ is the "to deliver" volume of the pipette in $\mathrm{mL}$ at the analytical temperature $(\mathrm{T}), \rho$ is the density of seawater in $\mathrm{kg} / \mathrm{mL}$ from the equation of state (Millero and Poisson 1981), and 1.00017 corrects for the dilution of the sample by the $100 \mu \mathrm{L}$ of $\mathrm{HgCl}_{2}$ solution added to the sample bottle.

As a consequence of the coulometer and gas calibration problems described in Sect. 2.3, BNL I was operated between September 13 and September 23 without a gas calibration system. For $\mathrm{TCO}_{2}$ calculations starting on September 13, the mean CALFAC of $1.002844(\mathbf{n}=7)$ obtained for the period September 4-10 was used. No samples were run on BNL I on September 11 and 12. BNL II was continuously operated between September 4 and 15 , and calculations were made with the daily gas calibration factors for that instrument. No samples were run on BNL II after September 15. The results of the CRM analyses are shown in Fig. 3 and summaryzed in Table 1.

Table 1. Summary of $\mathrm{CRM} \mathrm{TCO}_{2}$ analyses made aboard the $\mathrm{R} / \mathrm{V}$ Meteor during Cruise

\begin{tabular}{|c|c|c|c|c|c|c|c|}
\hline System & $\begin{array}{l}\text { No. } \\
\text { (n) }\end{array}$ & $\begin{array}{l}\text { Mean } \\
--(\mu \mathrm{m}\end{array}$ & SD & $\begin{array}{l}\text { R. S. D. } \\
(\%)\end{array}$ & 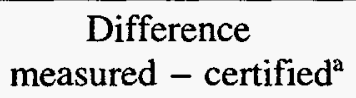 & & $\begin{array}{l}\text { Period } \\
(1991)\end{array}$ \\
\hline$\overline{B N L ~ I^{b}}$ & 14 & 1925.87 & 0.89 & 0.05 & -0.54 & $4-10$ & September \\
\hline BNL $I^{c}$ & 23 & 1925.33 & 1.46 & 0.08 & -1.08 & $13-23$ & 3 September \\
\hline BNL II & 24 & 1926.89 & 1.65 & 0.09 & +0.48 & $4-15$ & September \\
\hline Combined & 61 & 1926.07 & 1.58 & 0.08 & -0.32 & $4-23$ & September \\
\hline
\end{tabular}
18/1 (September 1991) with two SOMMA-Coulometer Systems (BNL I and BNL II).

aThe CRMs were from Batch 7 and had a salinity of 37.12 and a certified $\mathrm{TCO}_{2}$ of $1926.41 \pm 0.82 \mu \mathrm{mol} / \mathrm{kg}(\mathrm{n}=13)$.

bPeriod with gas calibration unit (September 4-10).

${ }^{\mathrm{c}}$ Period without gas calibration unit (September 13-22).

This was the first cruise during which two SOMMA systems were used side-by-side to analyze samples from the same profile and measurements of system precision and bias were made in addition to the CRM analyses. The system precision data are given in Table 2. For these data, "within-sample" precision was the average difference between two replicates analyzed from the same sample bottle, "between-sample" precision was the average difference between duplicate sample bottles taken from the same Niskin bottle, "between-Niskin" precision was the average difference between single sample bottles taken from two Niskin bottles closed at the same depth, and $S_{p}^{2}$ was the pooled standard deviation calculated from multiple "between-sample" replicates 


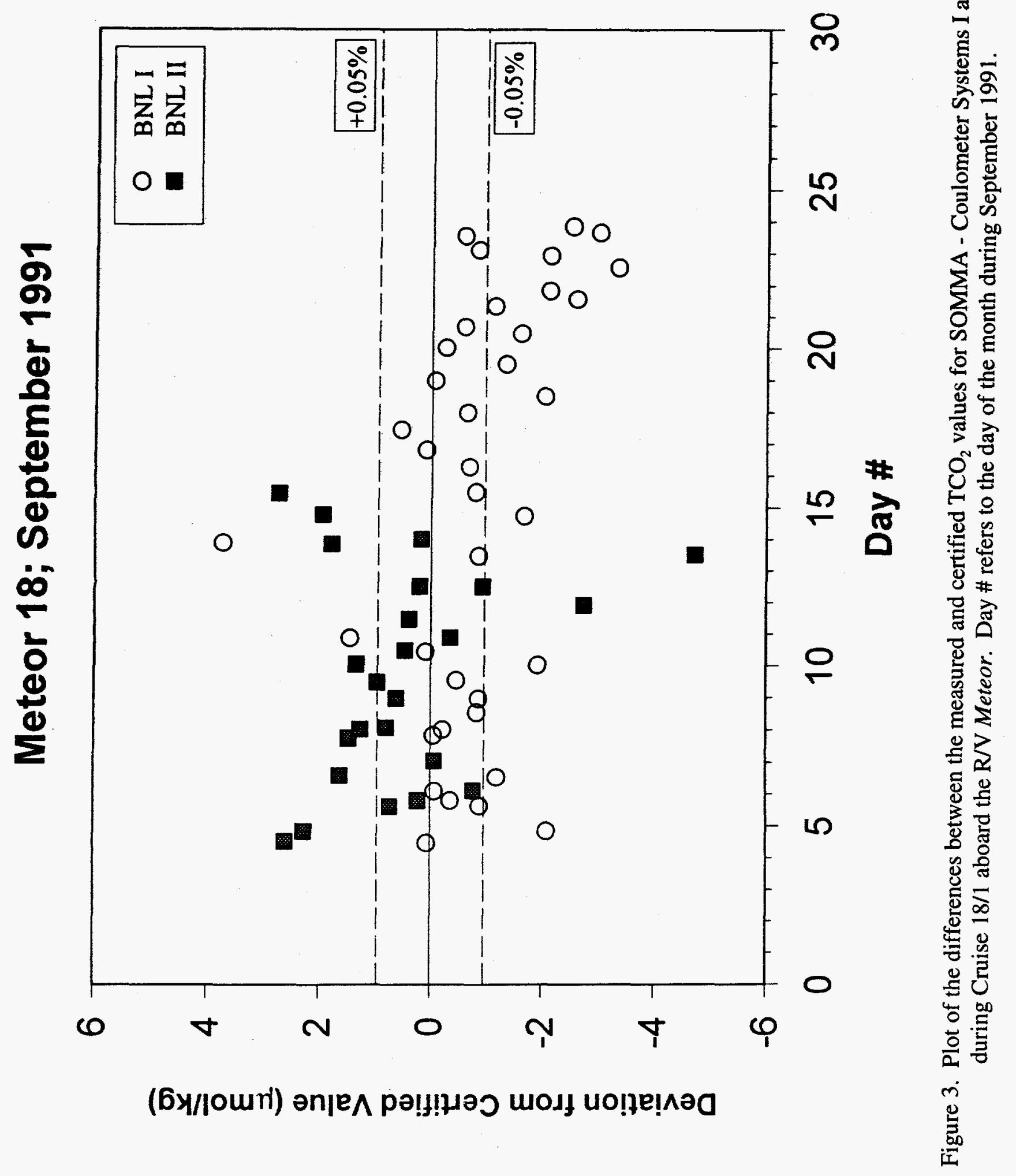


better than $S_{p}^{2}$. However, the higher value of $\pm 1.65 \mu \mathrm{mol} / \mathrm{kg}$ was considered to be the most conservative estimate of analytical precision because it includes all sources of error-random and systematic —encountered over several days.

System bias was also checked by comparing the calibration station (station 581) samples from a depth of $\sim 2033 \mathrm{~m}$ on both instruments over a period of 3-5 days. These data are shown in Table 3. For BNL I, the mean result was $2159.07 \pm 0.61 \mu \mathrm{mol} / \mathrm{kg}(n=5$, analyzed between September 12 and 16), and the corresponding result for BNL II was $2158.26 \pm 1.18 \mu \mathrm{mol} / \mathrm{kg}$ ( $n$ $=12$, analyzed between September 11 and 13). The absolute value of the difference was 0.81 $\mu \mathrm{mol} / \mathrm{kg}$ with BNL I giving a slightly higher result. The mean difference and the absolute value of the mean difference between duplicate analyses for the 34 samples used for the calculation of the method specific $S_{p}^{2}$ in Table 2 are shown in Table 3.

Table 3. Summary of $\mathrm{TCO}_{2}$ analyses for "between sample" duplicates, for which one of the duplicates was analyzed on SOMMA-Coulometer System BNL I and the other was analyzed on BNL II aboard the R/V Meteor during Cruise 18/1

\begin{tabular}{lccccc} 
Comparison & $K$ & BNL I $(n)$ & BNL II $(n)$ & Difference (I - II) & Abs (I - II) \\
\hline & & & & & \\
Station 581 & 1 & 2159.07 & 2158.26 & +0.81 & 0.81 \\
Samples, other & 34 & 2126.73 & 2128.38 & -1.65 & 1.65 \\
Mean & & & & -0.42 & 1.23 \\
\hline
\end{tabular}

Tables 1 and 3 show that BNL I gave slightly lower results in comparison with BNL II for the CRM, and most samples but that was reversed for the test station (581) samples. The sign differences for these data suggests that it would be unwarranted to assign a uniform instrument bias for the duration of the cruise, and accordingly, no correction for instrumental bias has been applied to the data. In effect, it has been decided to accept a conservative estimate of precision that includes an estimate of bias $( \pm 1.65 \mu \mathrm{mol} / \mathrm{kg}$, Table 2$)$ for any single measurement instead of applying a bias correction to the data from either instrument. In aggregate, Tables 1-3 indicate that a single $\mathrm{TCO}_{2}$ measurement is accurate and precise to $\pm 1.6 \mu \mathrm{mol} / \mathrm{kg}$.

As a final estimate of data quality, duplicate samples from seven Niskin bottles at five stations were collected for later shore-based reference analyses of $\mathrm{TCO}_{2}$ by vacuum extraction/manometry performed in the laboratory of Dr. Charles Keeling at SIO. The results are given in Table 4, in which the BNL data are compared with the SIO results (Guenther et al. 1994). All samples except the shallow sample from station 580 are clearly consistent with our estimate of accuracy and precision, given previously. Temperature sensors were not included in the shipping crates (as is now standard operating procedure), so the temperature history of these samples between cold storage aboard ship and their arrival at SIO was not known. Table 4 supersedes Tables 3e and 5e from Guenther et al. (1994). 
Table 4. Comparison of shipboard analyses of $\mathrm{TCO}_{2}$ by coulometry (BNL) during the R/V Meteor Cruise 18/1 and the shore-based reference analyses of $\mathrm{TCO}_{2}$ by manometry on duplicate samples in the laboratory of C. D. Keeling at SIO. The reference analyses were made February-March 1994.

\begin{tabular}{lllccccc}
\hline $\begin{array}{c}\text { Station } \\
\text { no. }\end{array}$ & $\begin{array}{l}\text { Sample } \\
\text { date }\end{array}$ & $\begin{array}{c}\text { Niskin } \\
\text { no. }\end{array}$ & $\begin{array}{c}\text { Depth } \\
(\mathrm{m})\end{array}$ & $\begin{array}{c}\mathrm{TCO}_{2}(\mathrm{BNL}) \\
(\mu \mathrm{mol} / \mathrm{kg})\end{array}$ & $\begin{array}{c}\mathrm{TCO}_{2}(\mathrm{SIO}) \\
(\mu \mathrm{mol} / \mathrm{kg})\end{array}$ & $\begin{array}{c}\text { Differ. } \\
\mathrm{BNL}-\mathrm{SIO}\end{array}$ & $\begin{array}{c}\text { Salinity } \\
\text { differ. }^{\mathrm{a}}\end{array}$ \\
\hline 575 & 09.09 .91 & 24 & 10 & 2088.25 & 2087.98 & +0.27 & +0.002 \\
575 & 09.09 .91 & 13 & 1095 & 2152.24 & 2154.55 & -2.31 & -0.019 \\
580 & 10.09 .91 & 23 & 27 & 2085.75 & 2094.58 & -8.83 & -0.003 \\
580 & 10.09 .91 & 1 & 2367 & 2157.52 & 2160.00 & -2.48 & -0.003 \\
$581^{\text {b }}$ & 10.09 .91 & 2 & 2033 & 2158.48 & 2158.73 & -0.25 & -0.004 \\
596 & 14.09 .91 & 14 & 690 & 2167.83 & 2167.74 & +0.09 & -0.005 \\
603 & 16.09 .91 & 1 & 4063 & 2202.42 & 2203.84 & -1.42 & -0.001 \\
\multicolumn{2}{l}{ Mean differences } & & & & & -2.13 & -0.005 \\
\hline
\end{tabular}

aThe difference between the ship's CTD sample salinity and the salinity measured at SIO.

${ }^{b}$ Calibration station. The BNL result is the mean of 17 analyses on the two systems between September 11 and 16.

Note that six of the seven differences were within the analytical precision of the methods, and salinities agreed to within 0.005 , which rules out evaporative losses.

Total Alkalinity samples were collected in $500-\mathrm{mL}$ bottles with the same precautions as for $\mathrm{TCO}_{2}$. Samples were stored in the dark at $4^{\circ} \mathrm{C}$ and analyzed within $24 \mathrm{~h}$. Samples were transferred into a closed titration cell with a volume of $\sim 120 \mathrm{~mL}$ and titrated at $25^{\circ} \mathrm{C} \pm 0.1^{\circ} \mathrm{C}$ with $0.1 \mathrm{M} \mathrm{HCl}$ containing $0.6 \mathrm{M} \mathrm{NaCl}$. The titration cell was based on the systems described by Bradshaw and Brewer (1988) and Millero et al. (1993). The potential was followed with an electrode pair consisting of a ROSS (Orion Inc.) glass $\mathrm{pH}$ electrode and a $\mathrm{ROSS} \mathrm{AgCl}$ reference electrode connected to a high-precision digital voltmeter. The titration was controlled by a computer, which waited for stable emf-readings before adding the next acid increment. The titration curve was analyzed with a modified GRAN-plot method described by Stoll et al. (1993), using the carbonic acid constants of Goyet and Poisson (1989), and taking into account the silicate and phosphate concentrations of the sample to obtain the titration alkalinity. The precision of the method was $\pm 2.0 \mu \mathrm{mol} / \mathrm{kg}$, which was determined by replicate analysis of samples. Standardization was accomplished with $\mathrm{NaCO}_{3}$ standards in $\mathrm{NaCl}$ solutions corrected for the blank arising from impurities in the salt.

Underway $\mathrm{pCO}_{2}$ was measured by using the method of Schneider et al. (1992). Surface seawater was continuously pumped along the cruise track (Fig. 3) at a rate of $200-300 \mathrm{~mL} / \mathrm{min}$ into a glass equilibrator with a volume of $-300 \mathrm{~mL}$. The seawater was equilibrated with continuously circulating air entering the bottom of the equilibrator through a frit from a closedloop system. This system included a heat exchanger to keep the air at sample temperature, a filter and water trap, and an infrared (IR) analyzer (Siemens, Ultrmat 5F) for the determination of the $\mathrm{CO}_{2}$ content of the equilibrated air. The infrared analyzer and equilibrator temperature sensor were connected to a computer or to an analog recorder for data display and preservation. The 


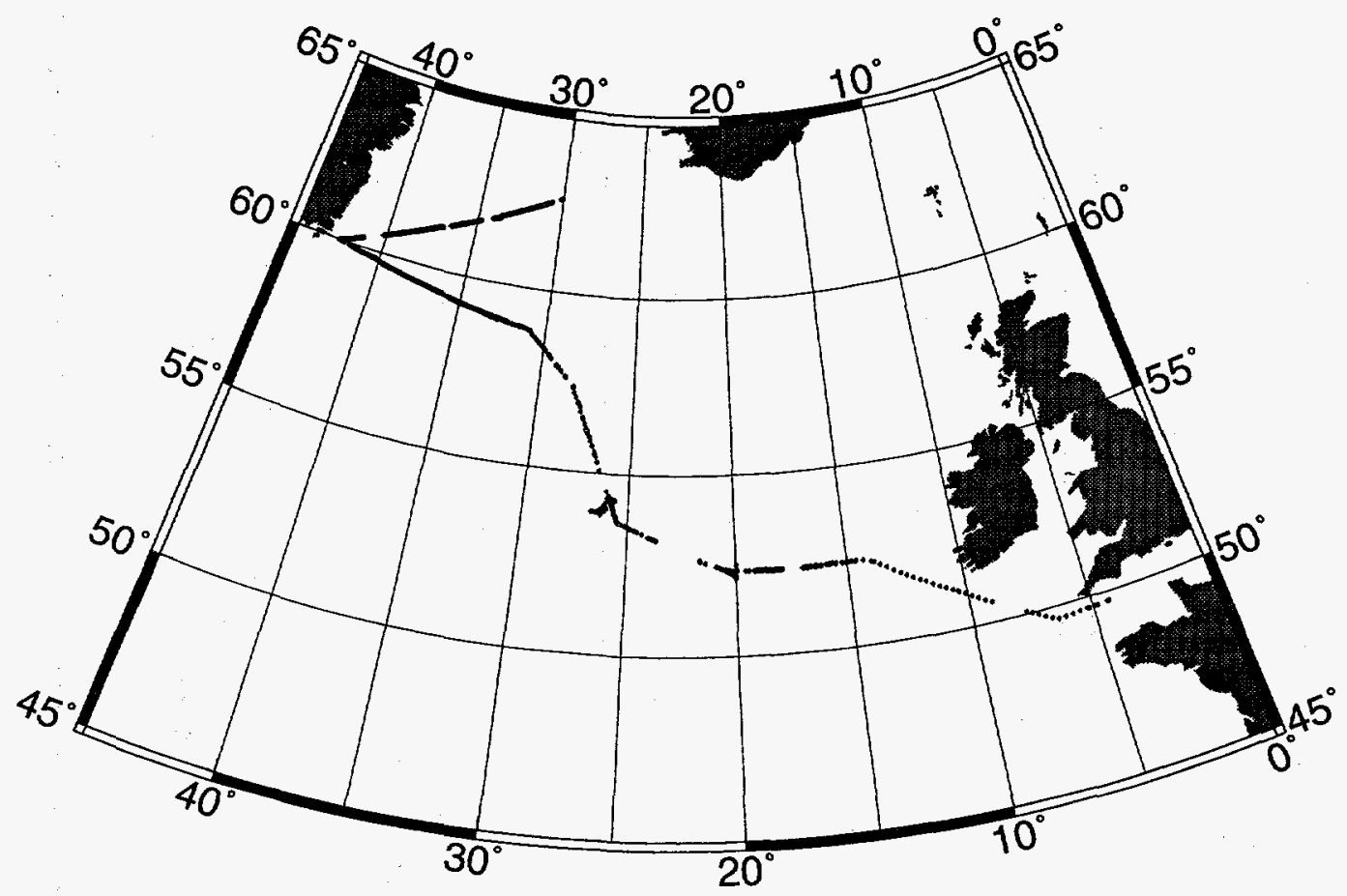

Figure 4. Track of underway $\mathrm{pCO}_{2}$ measurements made during R/V Meteor Cruise 18/1.

time constant for the equilibration was $\sim 3 \mathrm{~min}$, which corresponded to a spatial resolution of 0.5 mile with the ship steaming at 10 knots. Atmospheric air was periodically measured, and the system was calibrated every $12 \mathrm{~h}$ through the use of calibration gases with $\mathrm{CO}_{2}$ mixing ratios of 252.5 and $412.8 \mathrm{ppm}(\mathrm{v})$. Pressure corrections were made for the effect of water vapor on total pressure in the equilibrator and the pressure at the inlet of the IR analyzer; the correction for the difference between in situ temperature and measuring temperature was made according to Gordon and Jones (1973). Figure 4 presents the plots of the underway sea surface salinity, temperature, and $\mathrm{pCO}_{2}$ measured during $\mathrm{R} / \mathrm{V}$ Meteor Cruise 18/1. 


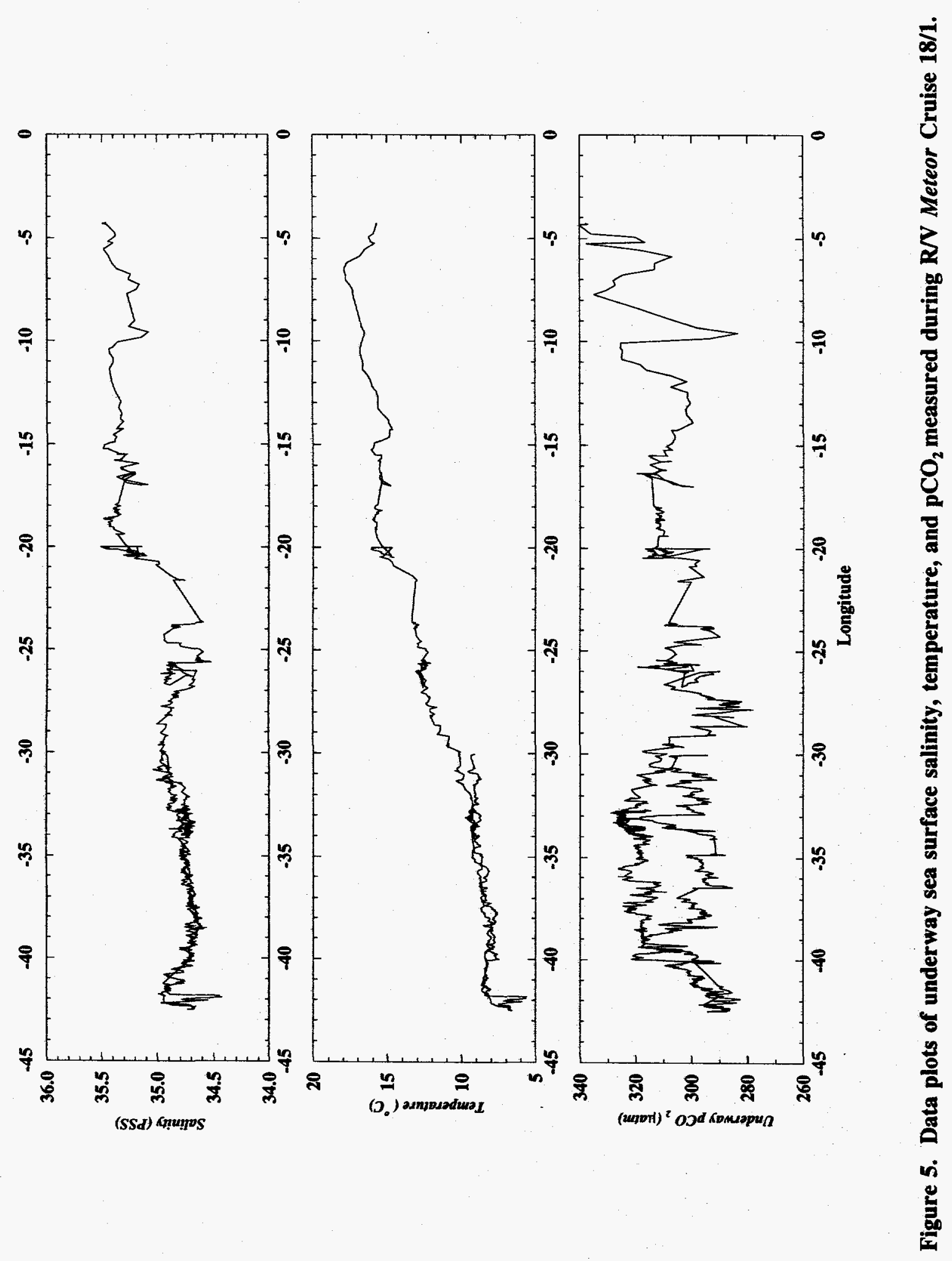




\section{DATA CHECKS AND PROCESSING PERFORMED BY CDIAC}

An important part of the NDP process at the Carbon Dioxide Information Analysis Center (CDIAC) involves the quality assurance (QA) of data before distribution. Data received at CDIAC are rarely in a condition that would permit immediate distribution, regardless of the source. To guarantee data of the highest possible quality, CDIAC conducts extensive QA reviews that involve examining the data for completeness, reasonableness, and accuracy. Although they have common objectives, these reviews are tailored to each data set, often requiring extensive programming efforts. In short, the QA process is a critical component in the value-added concept of supplying accurate, usable data.

The following summarizes the data processing and QA checks performed by CDIAC on the data obtained during the R/V Meteor Cruise 18/1 in the North Atlantic Ocean.

1. Carbon-related data and preliminary hydrographic measurements were provided to CDIAC by K. M. Johnson and D. W. R. Wallace of BNL. The final hydrographic and chemical measurements and the station information files were provided by the WOCE Hydrographic Program Office after quality evaluation. A FORTRAN 77 retrieval code was written and used to merge and reformat all data files.

2. To check for obvious outliers, all data were plotted using a PLOTNEST.C program written by Stewart C. Sutherland of Lamont-Doherty Earth Observatory. The program plots a series of nested profiles, using the station number as an offset; the first station is defined at the beginning, and subsequent stations are offset by a fixed interval (Figs. 5 and 6).

3. To identify "noisy" data and possible systematic, methodological errors, property-property plots for all parameters were generated (Fig. 7) and carefully examined.

4. All variables were checked for values that exceeded physical limits, such as sampling depth values exceeding the given bottom depths.

5. Dates, times, and coordinates were checked for bogus values (i.e., values of MONTH that were $<1$ or $>12$; DAY values $<1$ or $>31$; YEAR values $\neq 1991$; TIME values $<0000$ or $>2400$; LAT values $<49.000$ or $>65.000$; LONG values $<-43.000$ or $>-3.000$ ).

6. Station locations (latitudes and longitudes) and sampling times were examined for consistency with maps and with cruise information supplied by K. M. Johnson and D. W. R. Wallace, BNL.

7. The designation for missing values, given as -9.0 in the original files, was changed to -999.9 . 
woce section $\mathrm{AlF}$

only profiles which exist in this pressure (abar) range are plotted. plotted parameter ranges from 2000 to 2250

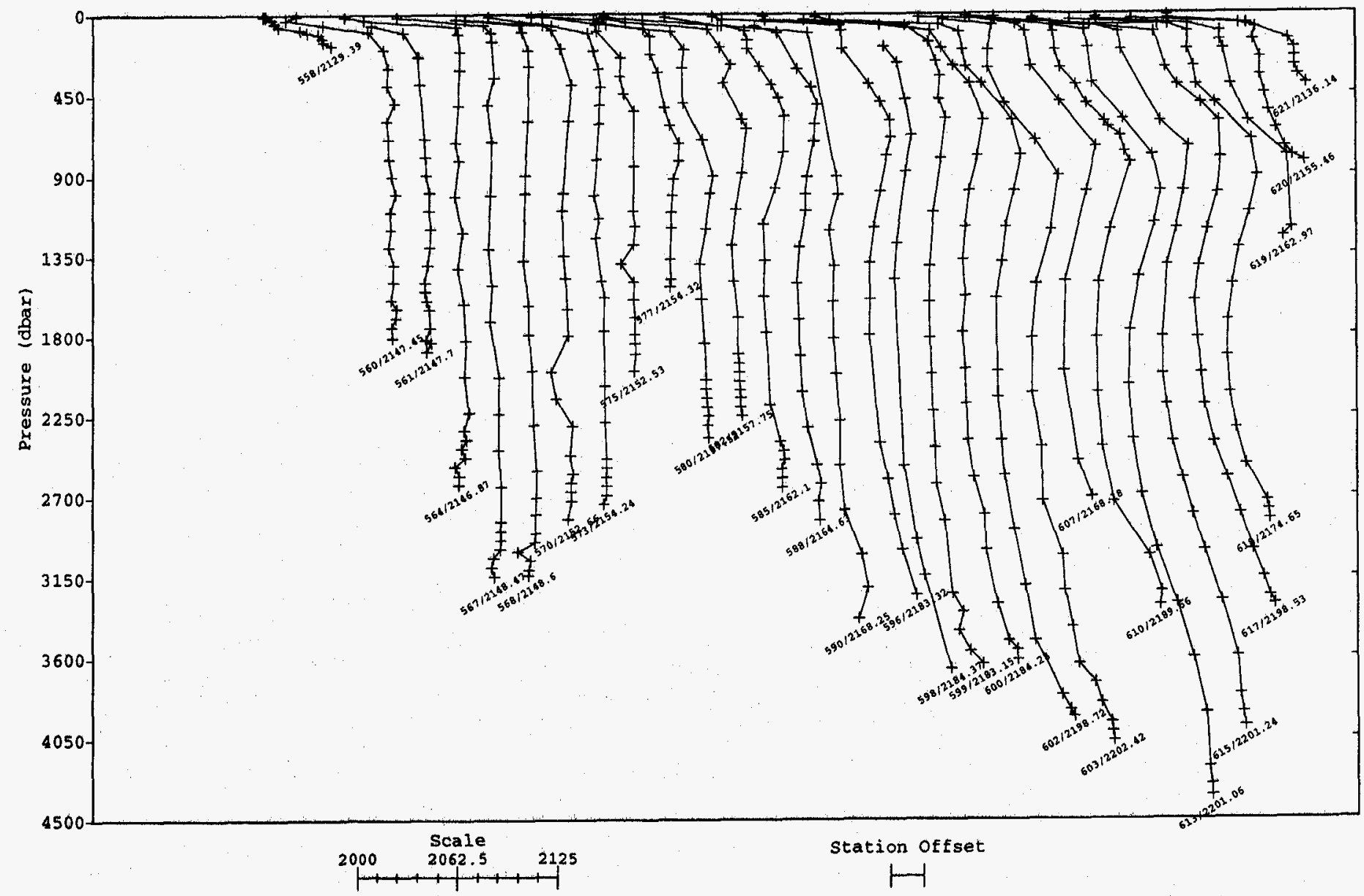

Figure 6. Nested profiles: Total carbon ( $\mu \mathrm{mol} / \mathrm{kg}$ ) vs pressure (dbar). 


\section{wOCE section MII}

Only profiles which exist in this Pressure (dbar) range are plotted. Plotted parameter ranges from 2250 to 2450

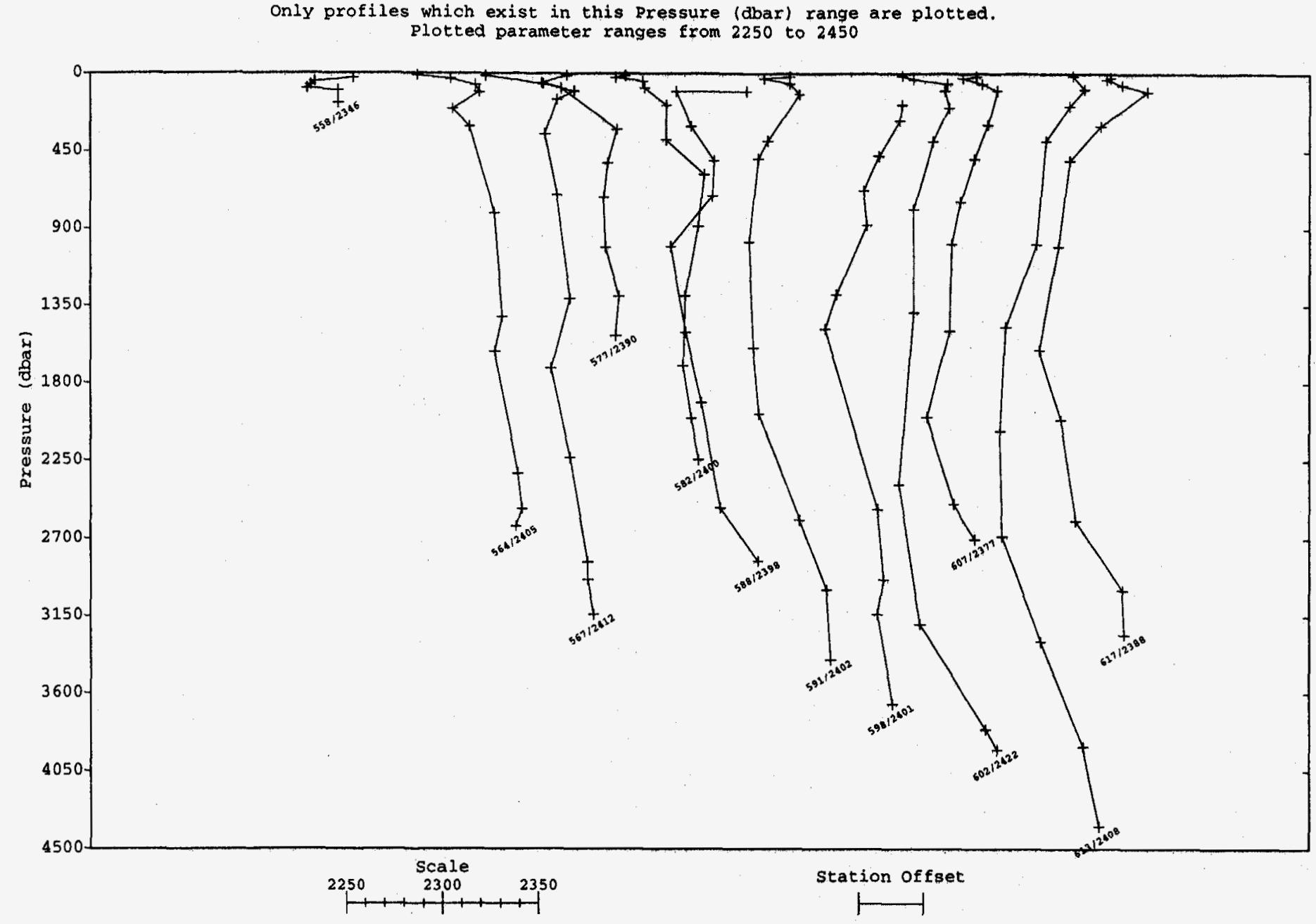

Figure 7. Nested profiles: Total alkalinity $(\mu \mathrm{mol} / \mathrm{kg})$ vs pressure (dbar). 

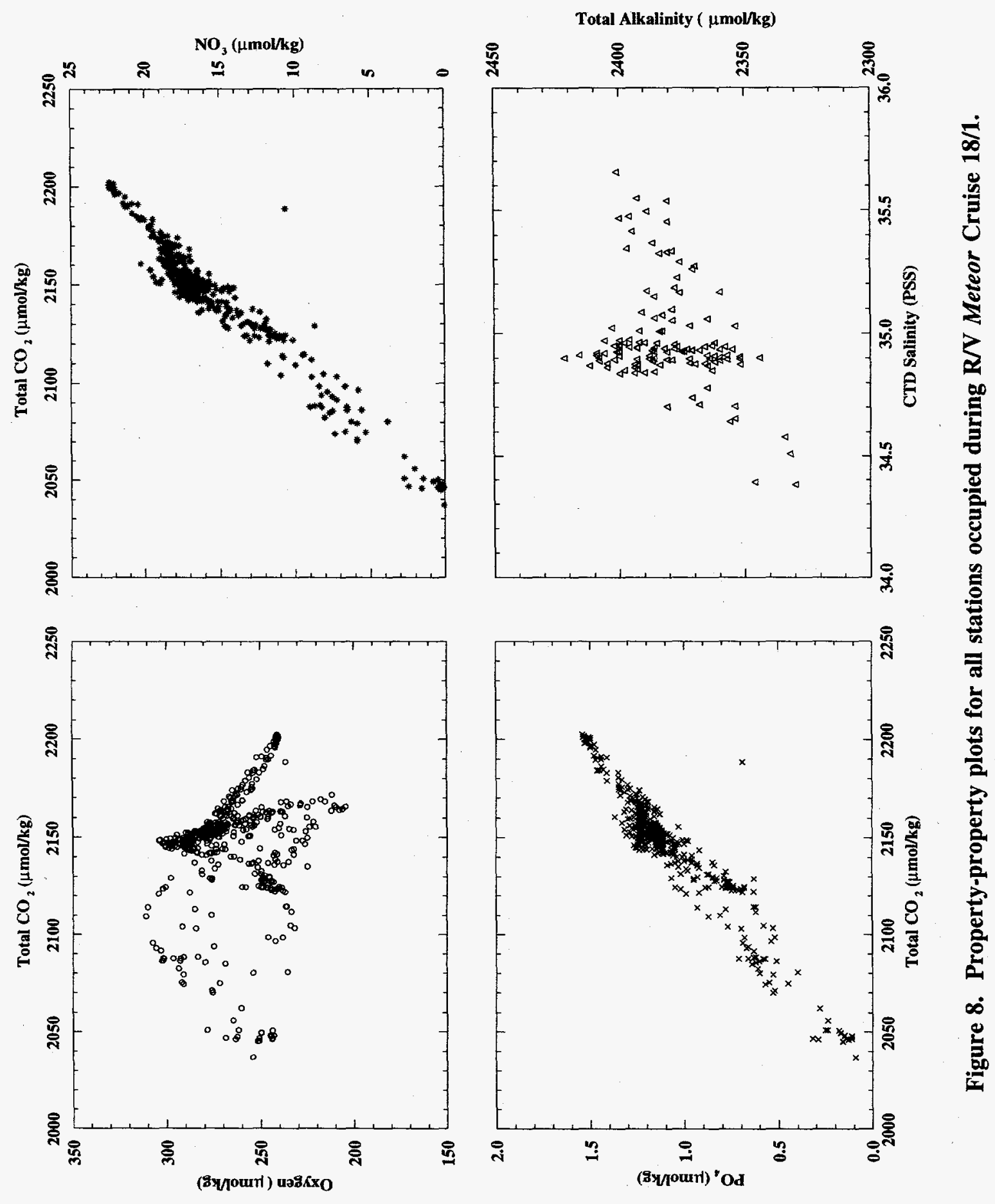


\section{HOW TO OBTAIN THE DATA AND DOCUMENTATION}

This database is available on request in machine-readable form, without charge, from CDIAC. CDIAC will also distribute subsets of the database as needed. It can be acquired on 9-track magnetic tape; 8-mm tape; 150-mB, 1/4-in. tape cartridge; IBM-formatted floppy diskettes; or from CDIAC's anonymous File Transfer Protocol (FTP) area through the Internet (see FTP address below). Requests should include any specific media instructions required by the user to access the data (i.e., 1600- or 6250-BPI, labeled or nonlabeled tapes, ASCII or EBCDIC characters, variable- or fixed-length records; 3.5- or 5.25-in. floppy diskettes, high or low density; 8200 or 8500 format, $8-\mathrm{mm}$ tape). Magnetic tape requests not accompanied by specific instructions will be filled on 9-track, 6250-BPI, standard-labeled tapes with EBCDIC characters. Requests should be send to the following address:

Carbon Dioxide Information Analysis Center

Oak Ridge National Laboratory

Post Office Box 2008

Oak Ridge, Tennessee 37831-6335

U.S.A.

Telephone: (423) $574-0390$ or (423) $574-3645$

Fax: $\quad$ (423) 574-2232

Electronic Mail: cdiac@ornl.gov

The data files can also be acquired from CDIAC's anonymous FTP area through the Internet by following these steps:

- FTP to cdiac.esd.ornl.gov (128.219.24.36),

- Enter "ftp" or "anonymous" as the user ID,

- Enter your electronic mail address as the password (e.g., "alex@alex.esd.ornl.gov”)",

- Change to the directory "/pub/ndp056", and

- Acquire the files by using the FTP "get" or "mget" command.

The data files can also be acquired through CDIAC's World Wide Web site at the following address:

- http://cdiac.esd.ornl.gov/oceans/home.html

${ }^{1}$ Please enter your correct address. This address is used by CDIAC to inform data recipients of data revisions and updates. 


\section{REFERENCES}

Armstrong, F. A. J., C. R. Stearns, and J. D. H. Strickland. 1967. The measurement of upwelling and subsequent biological processes by means of the Technicon Autoanalyzer and associated equipment: Deep-Sea Res. 14:381-89.

Atlas, E. L., S. W. Hager, L. L. Gordon, and P. K. Park. 1971. A Practical Manual for Use of the Technicon Autoanalyzer in Seawater Nutrient Analyses, Revised. Technical Report 215, Reference 71-22. Oregon State University, Department of Oceanography.

Bernhardt, H., and A. Wilhelms. 1967. The continuous determination of low level iron, soluble phosphate and total phosphate with the AutoAnalyzer (R). Technicon Symposia, Vol. I, 385-89.

Bradshaw, A. L., and P. G. Brewer. 1988. High precision measurements of alkalinity and total carbon dioxide in seawater by potentiometric titration-1. Presence of unknown protolyte(s). Mar. Chem., 23:69-86.

Brewer, P. G., C. Goyet, and D. Dyrssen. 1989. Carbon dioxide transport by ocean currents at $25^{\circ} \mathrm{N}$ latitude in the Atlantic Ocean. Science 246:477-79.

Bryden, H. L., and M. M. Hall. 1980. Heat transport by ocean currents across $25^{\circ} \mathrm{N}$ latitude in the North Atlantic Ocean. Science 207:884.

Carpenter, J. H. 1965. The Chesaspeake Bay Institute technique for the Winkler dissolved oxygen method. Limnol. Oceanogr. 10:141-43.

Culberson, C. H., and R. T. Will. 1991. A comparison of methods for the determination of dissolved oxygen in seawater. WHP Office Report, WHPO 91-2.

DOE (U.S. Department of Energy). 1994. Handbook of methods for the analysis of the various parameters of the carbon dioxide system in sea water. Ver. 2. ORNL/CDIAC-74. A. G. Dickson and C. Goyet (eds.). Carbon Dioxide Information Analysis Center, Oak Ridge National Laboratory, Oak Ridge, Tenn.

Gordon, L. I., and L. B. Jones. 1973. The effect of temperature on carbon dioxide partial pressure in seawater. Mar. Chem. 1:317-22.

Goyet, C., and A. Poisson. 1989. New determination of carbonic acid dissociation constants in seawater as a function of temperature and salinity. Deep-Sea Res. 36:1635-54.

Guenther, P. R., C. D. Keeling, and G. Emanuele III. 1994. Oceanic $\mathrm{CO}_{2}$ Measurements for the WOCE Hydrographic Survey in the Pacific Ocean, 1990-1991: Shore Based Analyses. SIO Reference Series, Ref. No. 94-28. University of California, San Diego, Calif.

Hager, S. W., E. L. Atlas, L. G. Gordon, A. W. Mantyla, and P. K. Park. 1972. A comparison at sea of manual and autoanalyzer analyses of phosphate, nitrate, and silicate. Limnol. Oceanogr. 17:931-37. 
Johnson, K. M., and D. W. R. Wallace. 1992. The single-operator multiparameter metabolic analyzer for total carbon dioxide with coulometric detection. DOE Research Summary, No. 19. Carbon Dioxide Information Analysis Center, Oak Ridge National Laboratory, Oak Ridge, Tenn.

Johnson, K. M., A. E. King, and J. M. Sieburth. 1985. Coulometric $\mathrm{TCO}_{2}$ analyses for marine studies: An introduction. Mar. Chem. 16:61-82.

Johnson, K. M., J. M. Sieburth, P. J. B. Williams, and L. Brändström. 1987. Coulometric TCO analysis for marine studies: Automation and calibration. Mar. Chem. 21:117-33.

Johnson, K. M., K. D. Wills, D. B. Butler, W. K. Johnson, and C. S. Wong. 1993. Coulometric total carbon dioxide analysis for marine studies: Maximizing the performance of an automated gas extraction system and coulometric detector. Mar. Chem. 44:167-87.

Johnson, K. M., D. W. R. Wallace, R. Wilke, and C. Goyet. 1995. Carbon dioxide, Hydrographic, and Chemical Data Obtained During the R/V Meteor Cruise 15/3 in the South Atlantic Ocean (WOCE Section A9, February-March 1991). Carbon Dioxide Information Analysis Center, Oak Ridge National Laboratory, Oak Ridge, Tenn.

Meincke, J. (ed.). 1993. WOCE-NORD 1991, Cruise No. 18, 2 September-26 September 1991. METEOR-Berichte No. 93-1. Institut für Meereskunde, Universität Hamburg, Germany.

Millero, F. J., and A. Poisson. 1981. International one-atmosphere equation of state for sea water. Deep-Sea Res. 28:625-29.

Millero, F. J., J.-Z. Zhang, K. Lee, and D. M. Campbell. 1993. Titration alkalinity of seawater. Mar. Chem. 44:153-65.

Roemmich, D., and C. Wunsch. 1985. Two transatlantic sections: Meridional circulation and heat flux in the subtropical North Atlantic Ocean. Deep-Sea Res. 32:619-64.

Ruhsam, C. M. 1994. WHP One-Time Section A9 Data Report. WOCE Special Analysis Center, Bundesamt für Seeschiffahrt and Hydrographie, Hamburg, Germany (unpublished manuscript).

Schneider, B., K. Kremling, and J. C. Duinker. 1992. $\mathrm{CO}_{2}$ partial pressure in northeast Atlantic and adjacent shelf waters: Processes and seasonal variability. J. Mar. Systems 3:453-63.

Siedler, G., and W. Zenk. 1992. WOCE Sudatlantik 1991, Reise Nr. 15, 30 Dezember 1990-23 Marz 1991. METEOR-Berichte 92-1. Universität Hamburg, Germany.

Stoll, M. H. C., J. W. Rommets, and H. J. W. De Baar. 1993. Effect of selected calculation routines and dissociation constants on the determination of total carbon dioxide in seawater. Deep-Sea Res. 40:1307-22. 
Wilke, R. J., D. W. R. Wallace, and K. M. Johnson. 1993. A water-based, gravimetric method for the determination of gas sample loop volume. Anal. Chem. 65:2403-06.

WOCE Operations Manual. 1991. WHP Office Report 90-1. Rev.1. Unpublished Manuscript. WOCE Hydrographic Programme Office. Woods Hole Oceanographic Institution, Woods Hole, Mass. (unpublished manuscript).

Youden, W. J. 1951. Statistical Methods for Chemists. Wiley, New York. 
PART 2:

CONTENT AND FORMAT OF DATA FILES 



\section{FILE DESCRIPTIONS}

This section describes the content and format of each of the seven files that compose this NDP (Table 5). Because CDIAC distributes the data set in several ways (e.g., by anonymous FTP, on floppy diskette, on 9-track magnetic tape), each of the five files is referenced by both a file number and an ASCII file name, which is given in lower-case, bold-faced type (e.g., readme). The remainder of this section describes or lists the contents of each file. The files are discussed in the order presented in Table 5.

Table 5. Content, size, and format of data files

File number, name, and description
Logical

records
File size

in bytes
Block

size

8,000

83,319

1,411

A detailed description of the cruise network, the three FORTRAN 77 data retrieval routines, and the three oceanographic data files

2. stainv.for:

A FORTRAN 77 data retrieval routine to read and print met18sta.inv (File 5)

3. met18dat.for:

A FORTRAN 77 data retrieval routine to read and print met18.dat (File 6)

4. uwpco2.for:

A listing of the station locations; sampling dates, and sounding bottom depths for all stations 
Table 5. (continued)

File number, name,

Logical

File size

Block

Record

and description

records

in bytes

size

length

6. met18.dat:

1,224

192,149

16,000

160

Hydrographic, carbon dioxide,

and nutrient data from all stations

7. uwpco2.dat:

Underway $\mathrm{pCO}_{2}$ data collected along

the cruise track

Total

4,949

418,258

\section{readme (File 1)}

This file contains a detailed description of the data set, the three FORTRAN 77 data retrieval routines, and the three oceanographic data files. It exists primarily for the benefit of individuals who acquire this database as machine-readable data files from CDIAC.

\section{stainv.for (File 2)}

This file contains a FORTRAN 77 data retrieval routine to read and print met18sta.inv (File 5). The following is a listing of this program. For additional information regarding variable definitions, variable lengths, variable types, units, and codes, please see the description for met18sta.inv on page 33 .

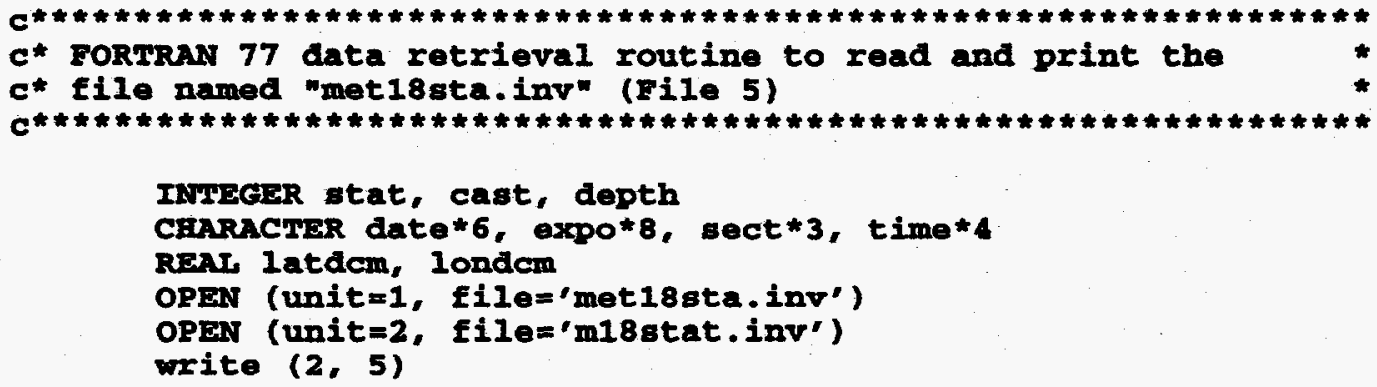


1 2X, 'EXPOCODE' , 2X, 'SECT', 2X, 'STMRBRR', 2X, 'CASMHO', 5X, 'DATE',

2 3X, 'TIKE', 5X, 'LATDCM', 5X, 'LONDCM', 3X, 'DEPTH', /)

6 read $(1,6)$

(1/1/1//1//1)

7 conrinos

read (1, 10, endi=999) expo, sect, stat, cast, date, time,

1 latdem, londcm, depth

10 Eormat $(2 \mathrm{x}, \mathrm{A8}, 3 \mathrm{x}, \mathrm{A3}, \mathrm{5x}, \mathrm{I3}, \mathrm{7x}, \mathrm{I1}, 3 \mathrm{x}, \mathrm{A6}, \mathrm{3x}, \mathrm{A4}, \mathrm{5x}$,

1 F6.3, 4X, F7.3, 4X, I4)

write $(2,20)$ expo, sect, stat, cast, date, time, latdom,

1 londem, depth

20 format $(2 \mathrm{X}, \mathrm{A8}, 3 \mathrm{x}, \mathrm{A3}, \mathrm{5X}, \mathrm{I3}, \mathrm{7X}, \mathrm{I1}, 3 \mathrm{x}, \mathrm{A6}, 3 \mathrm{x}, \mathrm{A4}, \mathrm{5x}$,

1 F6.3, 4x, $77.3,4 x, I 4)$

coro 7

999

close (unit=1)

close (unit $=2$ )

stop

end

\section{met18dat.for (File 3)}

This file contains a FORTRAN 77 data retrieval routine to read and print met18.dat (File 6). The following is a listing of this program. For additional information regarding variable definitions, variable lengths, variable types, units, and codes, please see the description for met18.dat on page 34 .

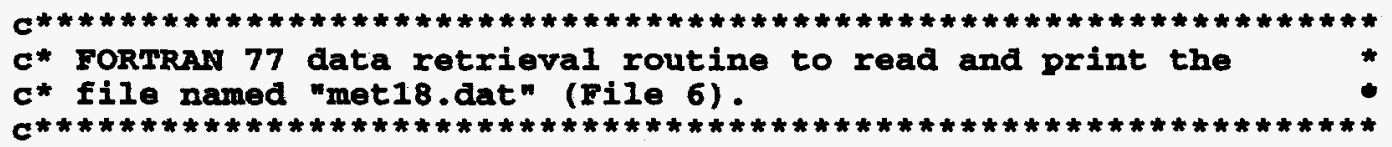

CHNRICHar bot*3, qua1t*10

INHzesa sta, cast, samp

REAr pre, ctdtmp, theta, revtmo, ctdsal, salt, oxygen, silcat

REnI nitrat, nitrit, phspht, tcarb, talk

OPEA (unit=1, file='met18.dat')

OPEI (unit=2, file='met18.data')

vrite $(2,5)$

5

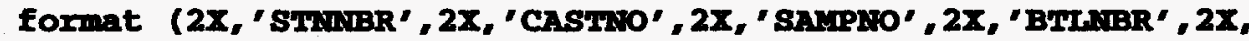

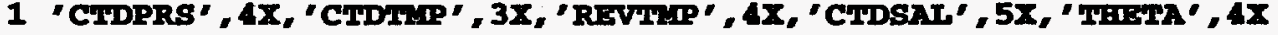

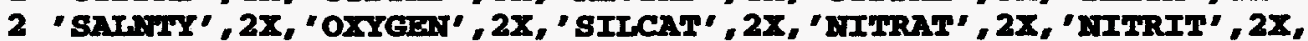

3 'PESPEY', 2X, "AITAII", 2X, 'TCARBA' , 6X, 'QUALT1', /, 36X, 'DBAR',

4 4X,'ITS-90', 3X, 'ITS-90', 4X, 'PSS-78', 7X, 'DEG', 4X, 'PSS-78', 1X,

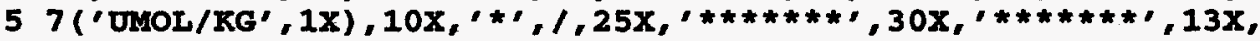

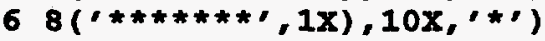

read $(1,6)$

6 format $(/ / / / / / / / / / / / /)$ 
1 revtmp, ctdsal, theta, salt, oxygen, silcat, nitrat, nitrit,

2 phspht, talk, tcarb, gualt

write (2, 20) sta, cast, samp, bot, pre, ctdtmp,

1 revtmp, ctdsal, theta, salt, oxygen, silcat, nitrat, nitrit,

2 phspht, talk, tcarb, gualt

GOTO 7

999 close (unit=1)

close (unit =2)

stop

end

\section{uwpco2.for (File 4)}

This file contains a FORTRAN 77 data retrieval routine to read and print uwpco2.dat (File 7). The following is a listing of this program. For additional information regarding variable definitions, variable lengths, variable types, units, and codes, please see the description for uwpco2.dat on page 36 .

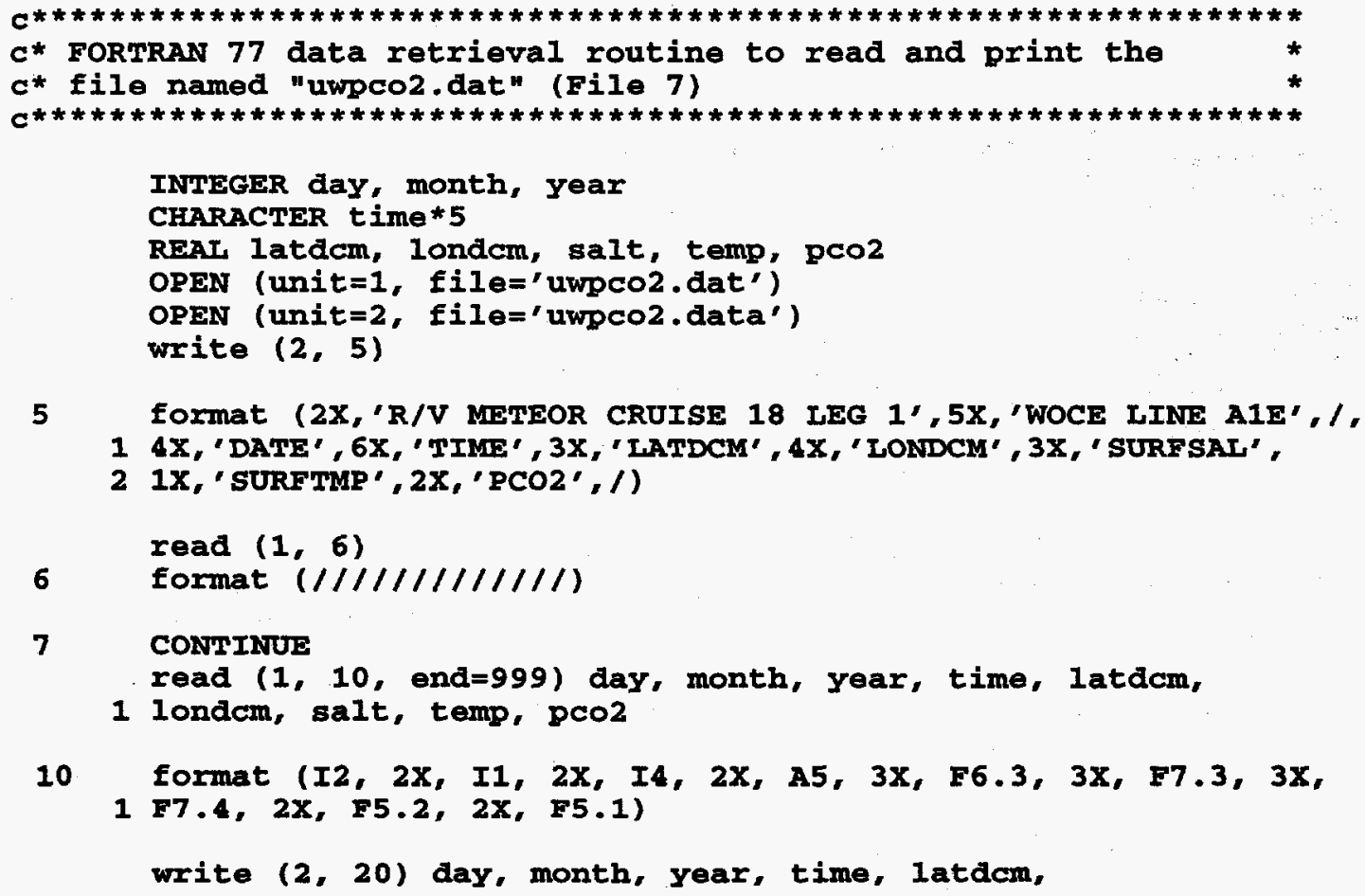


1 londcm, salt, temp, pco2

1 F7.4, 2X, F5.2, 2x, F5.1)

coro 7

close (unit $=2$ )

stop

end

\section{met18sta.inv (File 5)}

This file provides station inventory information for each of the 61 stations occupied during the R/V Meteor Cruise 18/1. Each line of the file contains an expocode, section number, station number, cast number, sampling date, sampling time, latitude, longitude, and sounding depth. The file is sorted by station number and can be read by using the following FORTRAN 77 code (contained in stainv.for, File 2):

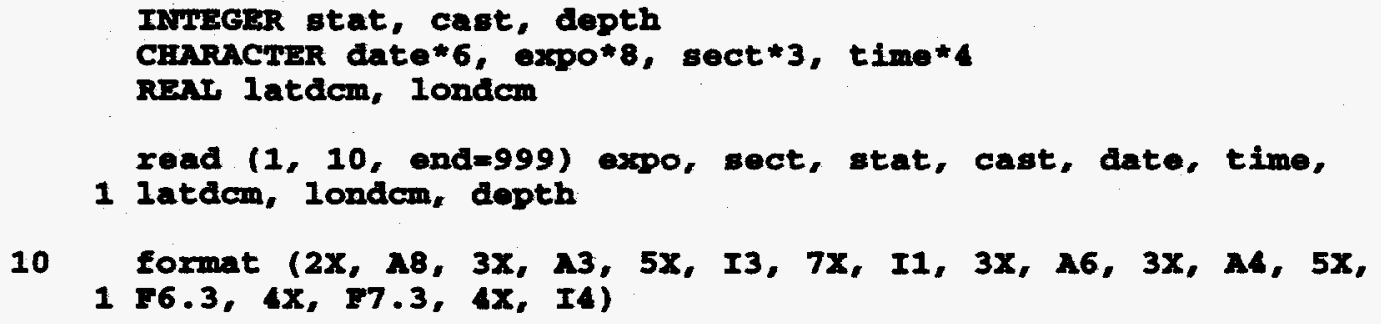

Stated in tabular form, the contents include the following:

\begin{tabular}{llccc}
\hline Variable & $\begin{array}{c}\text { Variable } \\
\text { type }\end{array}$ & $\begin{array}{c}\text { Variable } \\
\text { width }\end{array}$ & $\begin{array}{c}\text { Starting } \\
\text { column }\end{array}$ & $\begin{array}{c}\text { Ending } \\
\text { column }\end{array}$ \\
\hline expo & Character & 8 & 3 & 10 \\
sect & Character & 3 & 14 & 16 \\
stat & Numeric & 3 & 22 & 24 \\
cast & Numeric & 1 & 32 & 32 \\
date & Character & 6 & 36 & 41 \\
time & Character & 4 & 45 & 48 \\
latdcm & Numeric & 6 & 54 & 59 \\
londcm & Numeric & 7 & 64 & 70 \\
depth & Numeric & 4 & 75 & 78 \\
& & & & \\
\hline
\end{tabular}

where

expo is the expocode of the cruise (i.e., 06MT18/1); 
sect

is the WOCE section number (i.e., A1E);

stat

is the station number (values range from 558 to 622 );

cast

is the cast number;

date

is the sampling date (month/day/year);

time

is the sampling time (GMT);

latdem

is the latitude of the station (in decimal degrees; negative values indicate the Southern Hemisphere);

londem is the longitude of the station (in decimal degrees; negative values indicate the Western Hemisphere);

depth is the sounding depth of the station (in meters).

\section{met18.dat (File 6)}

This file provides hydrographic, carbon dioxide, and chemical data for the 61 stations occupied during R/V Meteor Cruise 18/1. Each line consists of a station number; cast number; sample number; bottle number; CTD pressure and temperature; potential temperature; reversing thermometer reading; CTD salinity; bottle salinity; concentrations of oxygen, silicate, nitrate, nitrite, phosphate, total carbon dioxide, and total alkalinity; and data quality flags. The file is sorted by station number and pressure and may be read by using the following FORTRAN 77 code (contained in met18dat.for, File 3):

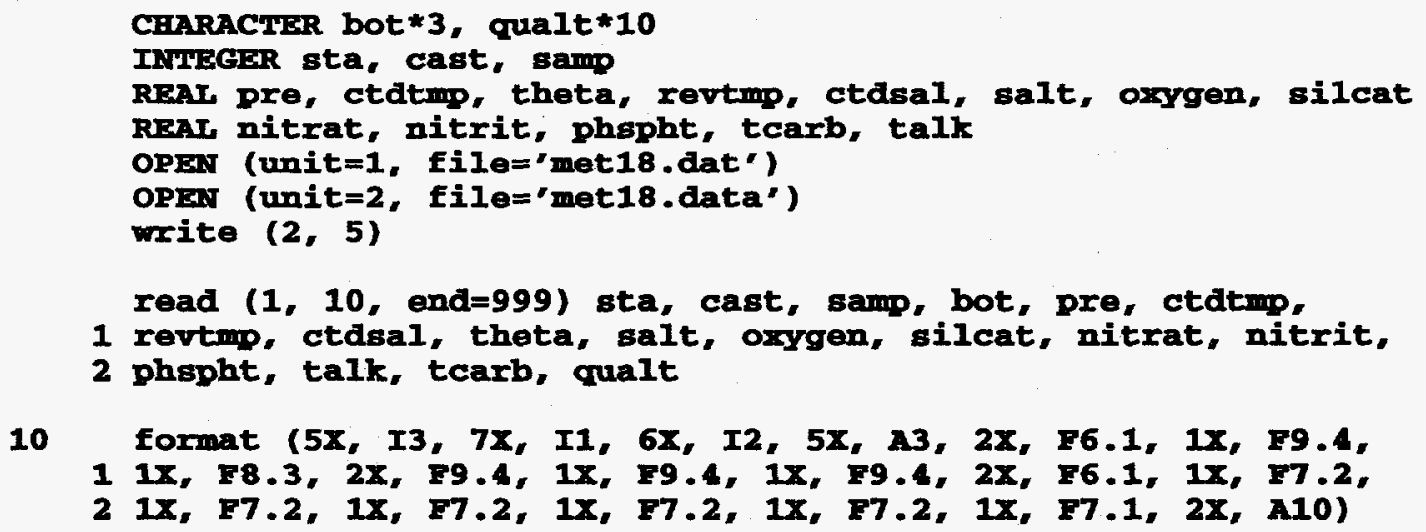

Stated in tabular form, the contents include the following: 


\begin{tabular}{llccc}
\hline Variable & $\begin{array}{c}\text { Variable } \\
\text { type }\end{array}$ & $\begin{array}{c}\text { Variable } \\
\text { width }\end{array}$ & $\begin{array}{c}\text { Starting } \\
\text { column }\end{array}$ & $\begin{array}{c}\text { Ending } \\
\text { column }\end{array}$ \\
\hline sta & Numeric & 3 & 6 & 8 \\
cast & Numeric & 1 & 16 & 16 \\
samp & Numeric & 2 & 23 & 24 \\
bot & Character & 3 & 30 & 32 \\
pre & Numeric & 6 & 35 & 40 \\
ctdtmp & Numeric & 9 & 42 & 50 \\
revtmp & Numeric & 8 & 52 & 59 \\
ctdsal & Numeric & 9 & 61 & 69 \\
theta & Numeric & 9 & 71 & 79 \\
salt & Numeric & 9 & 81 & 89 \\
oxygen & Numeric & 6 & 92 & 97 \\
silcat & Numeric & 7 & 99 & 105 \\
nitrat & Numeric & 7 & 107 & 121 \\
nitrit & Numeric & 7 & 115 & 129 \\
phspht & Numeric & 7 & 123 & 137 \\
talk & Numeric & 7 & 131 & 145 \\
tcarb & Numeric & 7 & 139 & 157 \\
qualt & Character & 10 & 148 & \\
\hline & & & & \\
\hline & & & & \\
\hline
\end{tabular}

where

\begin{tabular}{|c|c|}
\hline sta & is the station number; \\
\hline cast & is the cast number; \\
\hline samp & is the sample number; \\
\hline bot $^{*}$ & is the bottle number; \\
\hline pre & is the CTD pressure (dbar); \\
\hline ctdtmp & is the CTD temperature $\left({ }^{\circ} \mathrm{C}\right)$; \\
\hline revtmp & is the reversing thermometer reading $\left({ }^{\circ} \mathrm{C}\right)$; \\
\hline ctdsal $^{*}$ & is the CTD salinity [on the Practical Salinity Scale (PSS) \\
\hline theta & is the potential temperature $\left({ }^{\circ} \mathrm{C}\right)$; \\
\hline salt ${ }^{*}$ & is the bottle salinity; \\
\hline
\end{tabular}




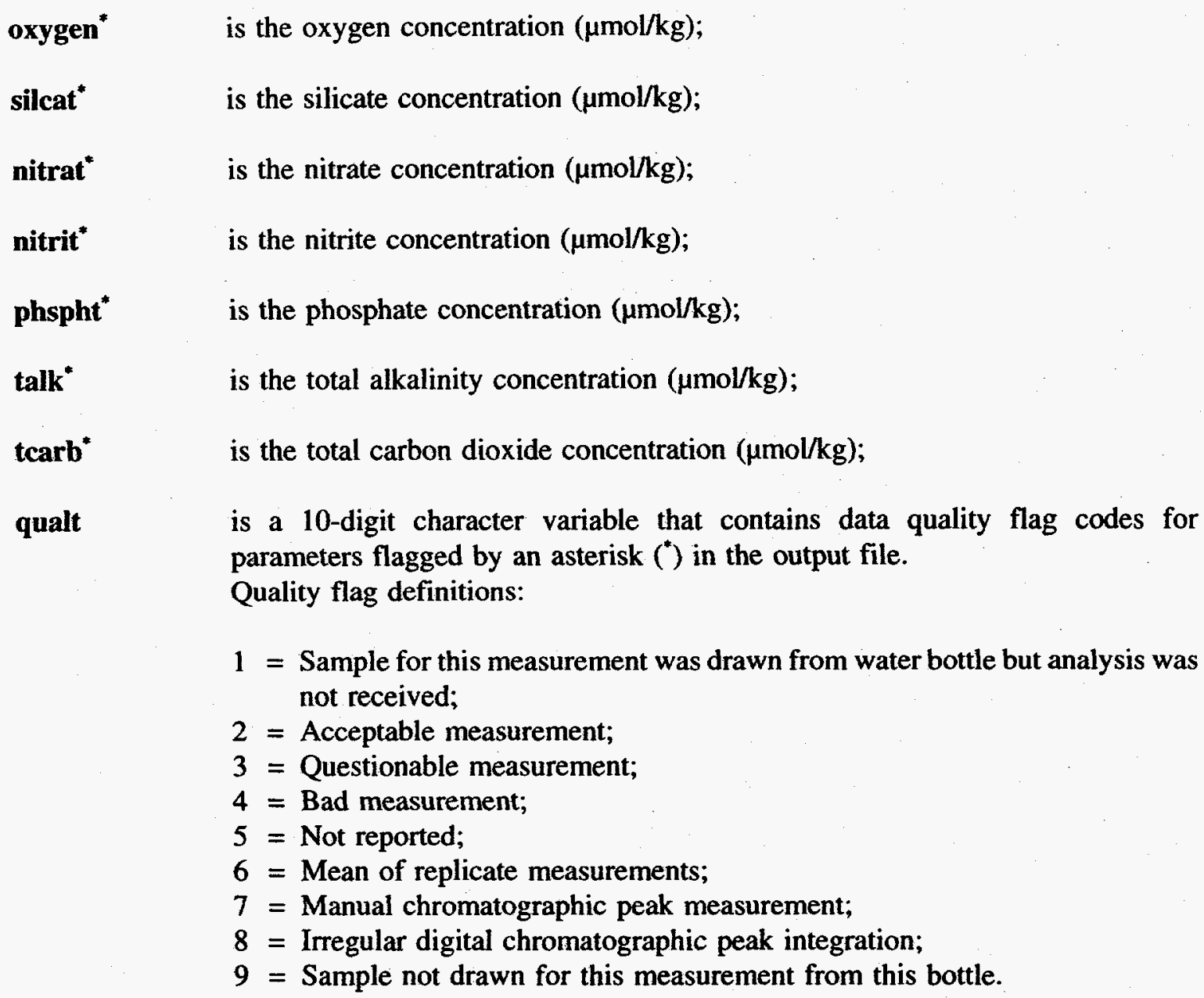

\section{uwpco2.dat (File 7)}

This file contains underway $\mathrm{pCO}_{2}$ measurements taken along the cruise track during the $\mathrm{R} / \mathrm{V}$ Meteor Cruise 18/1. Each line of the file contains a sampling date; sampling time; latitude; longitude; and measurements of sea surface salinity, temperature, and $\mathrm{pCO}_{2}$. The file is sorted by date and time and can be read by using the following FORTRAN 77 code (contained in uwpco2.for, File 4):

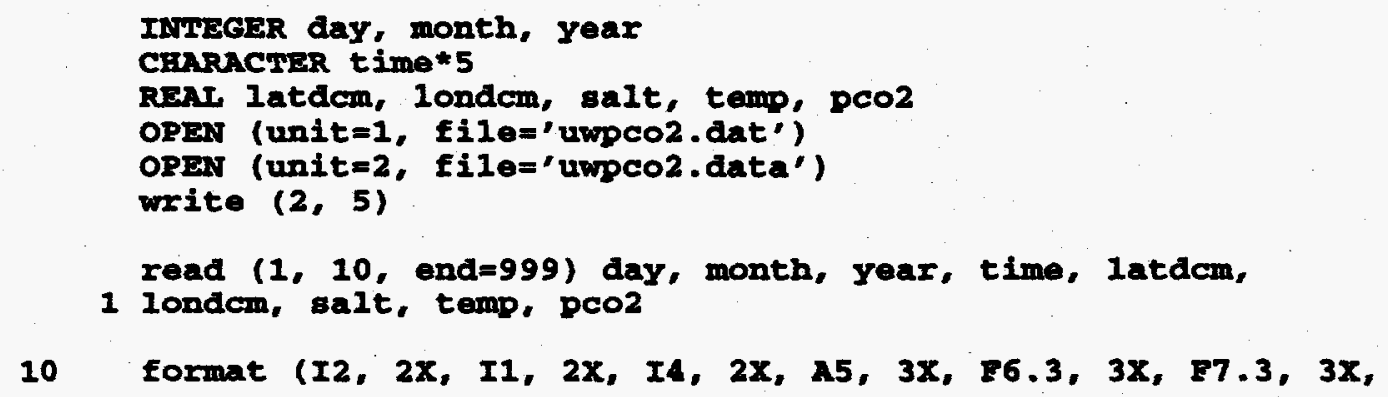


1 F7.4, 2X, F5.2, 2X, F5.1)

Stated in tabular form, the contents include the following:

\begin{tabular}{llccc}
\hline Variable & $\begin{array}{c}\text { Variable } \\
\text { type }\end{array}$ & $\begin{array}{c}\text { Variable } \\
\text { width }\end{array}$ & $\begin{array}{c}\text { Starting } \\
\text { column }\end{array}$ & $\begin{array}{c}\text { Ending } \\
\text { column }\end{array}$ \\
\hline day & Numeric & 2 & 1 & 2 \\
month & Numeric & 1 & 5 & 5 \\
year & Numeric & 4 & 8 & 11 \\
time & Character & 5 & 14 & 18 \\
latdcm & Numeric & 6 & 22 & 27 \\
londcm & Numeric & 7 & 31 & 37 \\
salt & Numeric & 7 & 41 & 47 \\
temp & Numeric & 5 & 50 & 54 \\
pco2 & Numeric & 5 & 57 & 61 \\
\hline
\end{tabular}

where

day is the sampling day;

month is the sampling month;

year is the sampling year;

time $\quad$ is the sampling time (GMT);

latdcm is the latitude of the station (in decimal degrees; negative values indicate the Southern Hemisphere);

londcm is the longitude of the station (in decimal degrees; negative values indicate the Western Hemisphere);

salt is the sea surface salinity;

temp is the sea surface temperature $\left({ }^{\circ} \mathrm{C}\right)$;

pco2 is the sea surface $\mathrm{pCO}_{2}$ ( $\mu$ atm). 


\section{VERIFICATION OF DATA TRANSPORT}

The data files contained in this NDP can be read by using the FORTRAN 77 data retrieval programs provided. Users should visually examine each data file to verify that the data were correctly transported to their systems. To facilitate the visual inspection process, partial listings of each data file are provided in Tables 6-8. Each of these tables contains the first and last five lines of a data file.

Table 6. Partial listing of "met18sta.inv" (File 5)

First five lines of the file:

\begin{tabular}{|c|c|c|c|c|c|c|c|c|}
\hline $\begin{array}{l}06 \mathrm{Mr18} / 1 \\
06 \mathrm{Mr18} / 1 \\
06 \mathrm{MP18} / 1 \\
06 \mathrm{Mr18} / 1 \\
06 \mathrm{MP18} / 1\end{array}$ & $\begin{array}{l}\mathrm{A} 1 \mathrm{E} \\
\mathrm{A} 1 \mathrm{E} \\
\mathrm{A} \mathrm{E} \\
\mathrm{A} 1 \mathrm{E} \\
\mathrm{A} 1 \mathrm{E}\end{array}$ & $\begin{array}{l}558 \\
559 \\
560 \\
561 \\
562\end{array}$ & $\begin{array}{l}1 \\
1 \\
1 \\
1 \\
1\end{array}$ & $\begin{array}{l}090591 \\
090591 \\
090591 \\
090591 \\
090691\end{array}$ & $\begin{array}{l}1346 \\
1607 \\
1855 \\
2242 \\
0251\end{array}$ & $\begin{array}{l}60.000 \\
59.967 \\
59.930 \\
59.895 \\
59.863\end{array}$ & $\begin{array}{l}-42.507 \\
-42.175 \\
-41.853 \\
-41.510 \\
-41.200\end{array}$ & $\begin{array}{r}185 \\
504 \\
1823 \\
1898 \\
2042\end{array}$ \\
\hline
\end{tabular}

Last five lines of the file:

\begin{tabular}{|c|c|c|c|c|c|c|c|c|}
\hline $\begin{array}{l}06 \mathrm{M} 18 / 1 \\
06 \mathrm{MP1} 18 / 1 \\
06 \mathrm{Mr} 18 / 1 \\
06 \mathrm{Mr} 18 / 1 \\
06 \mathrm{M} 18 / 1\end{array}$ & $\begin{array}{l}\text { A1E } \\
\text { A1E } \\
\text { A1E } \\
\text { A1E } \\
\text { A1E }\end{array}$ & $\begin{array}{l}618 \\
619 \\
620 \\
621 \\
622\end{array}$ & $\begin{array}{l}2 \\
1 \\
1 \\
1 \\
1\end{array}$ & $\begin{array}{l}092091 \\
092091 \\
092191 \\
092191 \\
092191\end{array}$ & $\begin{array}{l}1657 \\
2251 \\
0220 \\
0508 \\
0737\end{array}$ & $\begin{array}{l}52.335 \\
52.332 \\
52.333 \\
52.337 \\
52.333\end{array}$ & $\begin{array}{l}-15.500 \\
-15.218 \\
-14.932 \\
-14.643 \\
-14.253\end{array}$ & $\begin{array}{r}2834 \\
1262 \\
839 \\
417 \\
335\end{array}$ \\
\hline
\end{tabular}


Table 7. Partial listing of "met18.dat" (File 6)

First five lines of the file:

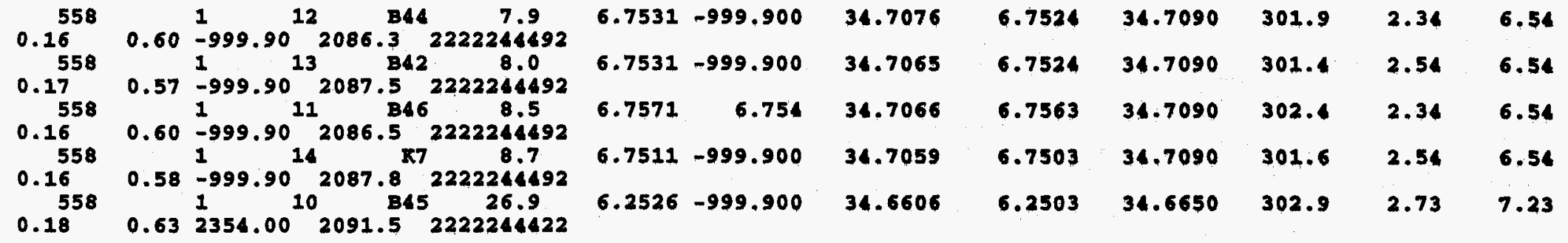

Last five lines of the file:

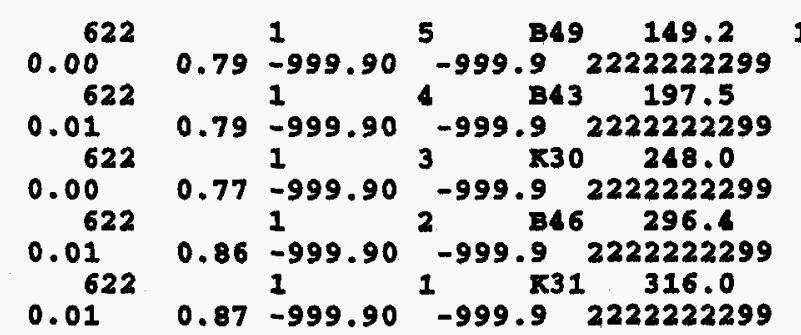

$10.0789-999.900$

$9.9849 \quad 9.988$

35.4284

10.0614

35.4340

248.

5.47

12.21

$9.9720-999.900$

35.4317

9.9619

35.4560

250.5

4.98

12.11

$9.8781 \quad 9.882$

35.4517

9.9430

35.4560

251.1

4.98

11.82

$9.8701-999.900$

35.4589

$9.8436 \quad 35.4610 \quad 241.3$

7.32

12.50

0.01

$0.87^{1}-999.90^{1}-999.9^{2222222299}$

9.8333

35.4620

239.1

8.01

12.60 
Table 8. Partial listing of "uwpco2.dat" (File 7)

First five lines of the file:

$\begin{array}{lllllllll}3 & 9 & 1991 & 20: 20 & 62.666 & -30.026 & 34.9400 & 9.13 & 294.3 \\ 3 & 9 & 1991 & 20: 25 & 62.660 & -30.057 & 34.9300 & 9.30 & 303.4 \\ 3 & 9 & 1991 & 20: 30 & 62.655 & -30.088 & 34.9267 & 9.37 & 307.9 \\ 3 & 9 & 1991 & 20: 35 & 62.648 & -30.120 & 34.9150 & 9.40 & 306.6 \\ 3 & 9 & 1991 & 20: 40 & 62.640 & -30.151 & 34.9133 & 9.40 & 305.3\end{array}$

Last five lines of the file:

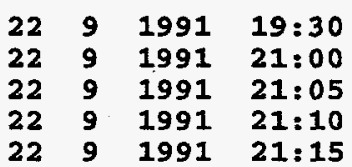

49.722

49.747

49.748

49.750

49.751

\begin{abstract}
$-4.782$
$-4.353$

$-4.329$

$-4.306$

$-4.282$
\end{abstract}

$\begin{array}{lll}35.3800 & 15.90 & 336.1 \\ 35.4600 & 15.70 & 340.2 \\ 35.4800 & 15.70 & 340.2 \\ 35.4950 & 15.65 & 337.2 \\ 35.4633 & 15.70 & 337.9\end{array}$




\section{APPENDIX A:}

\section{STATION INVENTORY}




\section{APPENDIX A: STATION INVENTORY}

This appendix lists station inventory information for the 61 sites occupied during the R/V Meteor Cruise 18/1 in the North Atlantic Ocean. The meanings of the column headings in Table A-1 are as follows.

EXPOCODE is the expocode of the cruise;

SECT is the WOCE section number;

STNNBR is the station number;

CASTNO is the cast number;

DATE is the sampling date (month/day/year);

TIME is the sampling time (GMT);

LATDCM is the latitude of the station (in decimal degrees). Stations in the Southern Hemisphere have negative latitudes;

LONDCM is the longitude of the station (decimal degrees). Stations in the Western Hemisphere have negative longitudes;

DEPTH is the sounding bottom depth (in meters). 
Table A.1 Station inventory information for the 61 sites occupied during R/V Meteor Cruise 18/1.

\begin{tabular}{|c|c|c|c|c|c|c|c|c|}
\hline EXPOCODE & SECT & STMNBR & CASTNO & DATE & TIME & LATDCM & LONDCM & DEPTH \\
\hline $\begin{array}{l}06 \mathrm{MP} 18 / 1 \\
06 \mathrm{MT} 18 / 1\end{array}$ & A1E & $\begin{array}{l}558 \\
559\end{array}$ & $\begin{array}{l}1 \\
1\end{array}$ & $\begin{array}{l}090591 \\
090591\end{array}$ & $\begin{array}{l}1346 \\
1607\end{array}$ & 60.000 & -42.507 & 185 \\
\hline 06MT18/1 & A1E & 560 & $\begin{array}{l}1 \\
1\end{array}$ & 090591 & $\begin{array}{l}1607 \\
1855\end{array}$ & $\begin{array}{l}59.963 \\
59.930\end{array}$ & $\begin{array}{l}-42.173 \\
-41.853\end{array}$ & $\begin{array}{r}504 \\
1823\end{array}$ \\
\hline $06 M T 18 / 1$ & $\mathbf{A 1 E}$ & 561 & 1 & 090591 & 2242 & 59.895 & -41.510 & 1898 \\
\hline $06 \mathrm{MP} 18 / 1$ & A1E & 562 & 1 & 090691 & 0251 & 59.863 & -41.200 & 2042 \\
\hline 06MT18/1 & $\mathbf{A} 1 \mathbf{E}$ & 563 & 1 & 090691 & 0657 & 59.833 & -40.867 & 2330 \\
\hline $06 M T 18 / 1$ & A1E & 564 & 1 & 090691 & 1138 & 59.787 & -40.205 & 2631 \\
\hline $06 M T 18 / 1$ & A1E & 565 & 1 & 090691 & 1624 & 59.705 & -39.590 & 2807 \\
\hline $06 \mathrm{MT} 18 / 1$ & AIE & 566 & 1 & 090691 & 2205 & 59.590 & -38.598 & 3013 \\
\hline $06 \mathrm{Mr} 18 / 1$ & A1E & 567 & 1 & 090791 & 1139 & 59.505 & -37.548 & 3129 \\
\hline $06 \mathrm{MP} 18 / 1$ & A1E & 568 & 1 & 090791 & 1701 & 59.402 & -36.648 & 3130 \\
\hline 06MT18/1 & A.IE & 569 & 1 & 090791 & 2210 & 59.335 & -35.943 & 3116 \\
\hline $06 M T 18 / 1$ & A1E & 570 & 1 & 090891 & 0348 & 59.233 & -35.002 & 2861 \\
\hline $06 \mathrm{MT} 18 / 1$ & A1E & 571 & 1 & 090891 & 1222 & 59.145 & -34.037 & 2855 \\
\hline $06 M T 18 / 1$ & A1E & 573 & 1 & 090991 & 0035 & 59.137 & -33.993 & 2734 \\
\hline $06 \mathrm{MT} 18 / 1$ & A1E & 574 & 1 & 090991 & 0453 & 59.077 & -33.403 & 2521 \\
\hline $06 \mathrm{MT} 18 / 1$ & $\mathbf{A} 1 \mathbf{E}$ & 575 & 1 & 090991 & 0920 & 59.013 & -32.772 & 2063 \\
\hline $06 M T 18 / 1$ & $\mathbf{A} 1 \mathbf{E}$ & 576 & 1 & 090991 & 1401 & 58.942 & -32.128 & 1752 \\
\hline $06 M T 18 / 1$ & A1E & 577 & 2 & 090991 & 2040 & 58.882 & -31.490 & 1550 \\
\hline 06MT18/1 & $\mathbf{A 1 E}$ & 578 & 1 & 091091 & 0041 & 58.798 & -30.832 & 1272 \\
\hline $06 M+18 / 1$ & $\mathbf{A} 1 \mathbf{E}$ & 579 & 1 & 091091 & 0437 & 58.562 & -30.387 & 1736 \\
\hline $06 \mathrm{MT} 18 / 1$ & A1E & 580 & 1 & 091091 & 0858 & 58.330 & -29.942 & 2369 \\
\hline $06 \mathrm{MT} 18 / 1$ & $\mathbf{A} 1 \mathbf{E}$ & 581 & 1 & 091091 & 1547 & 58.185 & -29.618 & 2070 \\
\hline $06 \mathrm{MP} 18 / 1$ & $\mathbf{A 1 E}$ & 582 & 1 & 091091 & 1944 & 58.085 & -29.500 & 2252 \\
\hline 06MT18/1 & A1E & 583 & 1 & 091191 & 0020 & 57.858 & -29.057 & 2333 \\
\hline $06 \mathrm{MP} 18 / 1$ & $\mathbf{A} \mathbf{E}$ & 584 & 1 & 091191 & 0519 & 57.617 & -28.635 & 2420 \\
\hline $06 \mathrm{MT} 18 / 1$ & A1E & 585 & 1 & 091191 & 1321 & 57.370 & -28.158 & 2645 \\
\hline 06 MT18/1 & AIE & 586 & 1 & 091191 & 2005 & 56.912 & -27.840 & 2922 \\
\hline $06 \mathrm{MT} 18 / 1$ & A1E & 587 & 1 & 091291 & 0242 & 56.460 & -27.493 & 2779 \\
\hline $06 \mathrm{MT} 18 / 1$ & A1E & 588 & 1 & 091291 & 0950 & 55.992 & -27.125 & 2819 \\
\hline $06 \mathrm{MT} 18 / 1$ & $\mathbf{A 1 E}$ & 589 & 1 & 091291 & 1545 & 55.533 & -26.800 & 3194 \\
\hline $06 \mathrm{MT} 18 / 1$ & A1E & 590 & 1 & 091291 & 2159 & 55.068 & -26.460 & 3378 \\
\hline $06 \mathrm{MT} 18 / 1$ & A1E & 591 & 1 & 091391 & 0505 & 54.610 & -26.118 & 3420 \\
\hline $06 \mathrm{MT} 18 / 1$ & A1E & 592 & 1 & 091491 & 0256 & 53.865 & -26.285 & 3643 \\
\hline $06 \mathrm{MT} 18 / 1$ & A1E & 593 & 1 & 091491 & 0656 & 54.033 & -26.018 & 3319 \\
\hline $06 \mathrm{MT} 18 / 1$ & A1E & 595 & 1 & 091491 & 1407 & 54.265 & -25.600 & 2554 \\
\hline 06MP18/1 & $\mathbf{A 1 E}$ & 596 & 1 & 091491 & 1741 & 54.377 & -25.950 & 3229 \\
\hline 06MT18/1 & A1E & 597 & 1 & 091491 & 2254 & 54.155 & -25.762 & 3156 \\
\hline $06 \mathrm{MT} 18 / 1$ & A1E & 598 & 1 & 091591 & 0334 & 53.920 & -25.637 & 3622 \\
\hline $06 \mathrm{MT} 18 / 1$ & A1E & 599 & 1 & 091591 & 1120 & 53.672 & -25.425 & 3626 \\
\hline $06 \mathrm{MT} 18 / 1$ & A1E & 600 & 1 & 091591 & 1715 & 53.463 & -24.685 & 3570 \\
\hline $06 \mathrm{MT} 18 / 1$ & A1E & 601 & 1 & 091591 & 2340 & 53.267 & -23.898 & 3718 \\
\hline $06 \mathrm{MT} 18 / 1$ & A1E & 602 & 1 & 091691 & 0559 & 53.068 & -23.130 & 3875 \\
\hline $06 \mathrm{MT} 18 / 1$ & A1E & 603 & 1 & 091691 & 1236 & 52.858 & -22.377 & 4005 \\
\hline $06 \mathrm{MT} 18 / 1$ & A1E & 604 & 1 & 091691 & 1846 & 52.655 & -21.613 & 3990 \\
\hline $06 \mathrm{MT} 18 / 1$ & A1E & 605 & 1 & 091791 & 0114 & 52.467 & -20.863 & 3739 \\
\hline $06 \mathrm{MT} 18 / 1$ & A1E & 607 & 1 & 091791 & 1601 & 52.497 & -20.000 & 2803 \\
\hline $06 \mathrm{Mr} 18 / 1$ & A1E & 608 & 1 & 091791 & 2123 & 52.175 & -19.993 & 3783 \\
\hline $06 \mathrm{MT} 18 / 1$ & A1E & 609 & 1 & 091891 & 0345 & 52.358 & -20.468 & 3646 \\
\hline 06 MT18/1 & A1E & 610 & 1 & 091891 & 0920 & 52.337 & -20.000 & 3308 \\
\hline $06 M T 18 / 1$ & A1E & 611 & 1 & 091891 & 1459 & 52.337 & -19.412 & 3600 \\
\hline $06 \mathrm{MT} 18 / 1$ & A1E & 612 & 1 & 091891 & 2103 & 52.323 & -18.620 & 4329 \\
\hline $06 M T 18 / 1$ & A1E & 613 & 1 & 091991 & 0402 & 52.332 & -17.815 & 4292 \\
\hline $06 \mathrm{MP} 18 / 1$ & A1E & 615 & 1 & 091991 & 1859 & 52.327 & -16.988 & 3931 \\
\hline 06 MT18/1 & A1E & 616 & 1 & 092091 & 0119 & 52.325 & -16.202 & 3465 \\
\hline $06 M T 18 / 1$ & A1E & 617 & 1 & 092091 & 0706 & 52.338 & -15.772 & 3273 \\
\hline $06 \mathrm{MP} 18 / 1$ & $\mathbf{A} 1 \mathbf{E}$ & 618 & 1 & 092091 & 1207 & 52.335 & -15.502 & 2839 \\
\hline 06MT18/1 & A1E & 618 & 2 & 092091 & 1657 & 52.335 & -15.500 & 2834 \\
\hline $06 \mathrm{MT} 18 / 1$ & A1E & 619 & 1 & 092091 & 2251 & 52.332 & -15.218 & 1262 \\
\hline $06 M T 18 / 1$ & A.1E & 620 & 1 & 092191 & 0220 & 52.333 & -14.932 & 839 \\
\hline $06 \mathrm{MT} 18 / 1$ & A1E & 621 & 1 & 092191 & 0508 & 52.337 & -14.643 & 417 \\
\hline 06 MP18/1 & A.1E & 622 & 1 & 092191 & 0737 & 52.333 & -14.253 & 335 \\
\hline
\end{tabular}


ORNL/CDIAC-91

NDP-056

\section{INTERNAL DISTRIBUTION}

1. L. D. Bates

2. B. A. Berven

3. T. A. Boden

4. R. B. Cook

5. J. H. Cushman

6. R. M. Cushman

7. V. H. Dale

8. M. P. Farrell

9. D. E. Fowler

10. R. L. Graham

11. S. G. Hildebrand

12. G. K. Jacobs

13. P. Kanciruk

14. D. P. Kaiser

15. A. Kozyr

16. J. M. Loar

17. D. E. Reichle

18. F. E. Sharples

19. D. E. Shepherd

20-219. CDIAC

221. Central Research Library

222-223. ESD Library

224-225. Laboratory Records Department

226. Laboratory Records, RC

227. ORNL Patent Office

228. ORNL Y-12 Technical Library

\section{EXTERNAL DISTRIBUTION}

229. William Asher, Marine Sciences Laboratory, Pacific Northwest Laboratory, 1529 West Sequim Bay Road, Sequim, WA 98382

230. James R. Akse, Umpqua Research Company, P.O. Box 791-125 Volunteer Way, Myrtle Creek, OR 97457

231. S. S. Alexander, Pennsylvania State University, Department of Geosciences, 503 Deike Building, University Park, PA 16802

232. J. H. Allen, National Oceanic and Atmospheric Administration, National Geophysical Data Center Code E/GC2, 325 Broadway, Boulder, CO 80303 
233. D. Alvic, EERC/UT, Pellissippi Office, Ste. 100, 10521 Research Drive, Knoxville, TN 37932

234. Robert F. Anderson, Lamont-Doherty Earth Observatory, Columbia University, Palisades, NY 10964

235. Colin Attwood, Sea Fisheries Research Institute, Private Bag X2 Roggebaai, 8012, South Africa

236. Donald K. Atwood, NOAA/AOML/OCD, 4301 Rickenbacker Causeway, Miami, FL 33149

237. Rich Barber, Duke University of North Carolina Oceanographic Consortium, Duke University Marine Laboratory, Beaufort, NC 28516

238. R. C. Barry, University of Colorado, World Data Center A, Glaciology, CIRES, Campus Box449, Boulder, CO 80309-0449

239. Jim Bauer, Department of Oceanography, B-169, Florida State University, Tallahassee, FL 32306-3048

240. Robert Bidigare, University of Hawaii, 1000 Pope Road, Honolulu, HI 96822

241. Peter G. Brewer, Monterey Bay Aquarium Research Institute, 160 Central Avenue, Pacific Grove, CA 93950

242. John A. Brimble, UIC, Inc., P.O. Box 83, 1225 Channahon Road, Joliet, IL 60434-0863

243. Jose Joaquin Hernandex Brito, Facultad de Ciencias del Mar, Dep. Quimica, Universidad de las Palmas, AP. 550, Las Palmas 35017, Spain

244. Michelle Broido, Acting Director, Environmental Sciences Division, Office of Health and Environmental Research, Department of Energy, ER-74, 19901 Germantown Road, Germantown, MD 20874-1290

245. Otis B. Brown, University of Miami, 4600 Rickenbacker Causeway, Miami, FL 33149

246. Lutz Brugmann, Department of Geology and Geochemistry, Stockholm University, S-106 91 Stockholm, Sweden

247. Alexander S. Bychkov, Climate Chemistry Laboratory, 43, Baltiyskaya Street, Vladivostok, 690041 Russia

248. Robert H. Byrne, University of South Florida, Department of Marine Science ,140 Seventh Avenue South, St. Petersburg, FL 33701-5016

249. M. A. Chinnery, National Oceanic and Atmospheric Administration, National Geophysical Data Center Code E/GC2, 325 Broadway, Boulder, CO 80303

250. David W. Chipman, Lamont-Doherty Earth Observatory of Columbia University, Climate/Environment/Ocean Division, RT 9W, Palisades, NY 10964-8000 
251. Y. Collos, Laboratoire d'Hydrobiologie, Univ. Montpellier, CC093 34095 Montpellier Cedex 5, France

252. Claire Copin-Montegut, Laboratoire de Physique et Chimie Marines, Universite Pierre et Marie Curie, Quai de la Darse BP 8, 06230 Villefranche sur Mer, France

253. Greg Cutter, Department of Oceanography, Old Dominion University, Norfolk, VA 23529-0276

254. Giovanni Daneri, Dept De Oceanografia y Biologia Pesquera, CEA Universidad Del Mar, Amunategui 1838, Vina Del Mar, Chile

255. Hein J. W. de Baar, Netherlands Institute for Sea Research, P.O. Box 59 1790, Ab den Burg, Texel, The Netherlands

256. Thomas Dickey, University of Southern California, Ocean Physics Group, Los Angeles, CA 90007

257. Andrew G. Dickson, University of California, Marine Physical Laboratory-0902 9500 Gilman Drive, La Jolla, CA 92093-0902

258. Scott Doney, Oceanography Section, NCAR, PO Box 3000, Boulder, CO 80307

259. W. Draeger, EROS Data Center, U.S. Geological Survey, Sioux Falls, SD 57198

260. M. Dryer, National Oceanic and Atmospheric Administration, Space Environmental Lab., ERL/OAR, R/E/SE, 320 Broadway, Boulder, CO 80303

261. Hugh W. Ducklow, Woods Hole Oceanographic Institution, Clark 4th Floor, Woods Hole, MA 02543

262. Brian J. Eadie, Great Lakes Environmental Research Laboratory, NOAA U.S. Department of Commerce, 2205 Commonwealth Blvd., Ann Arbor, MI 48105

263. J. F. Farvolden, Professor, Department of Earth Sciences, University of Waterloo, Waterloo, Ontario N2L 3G1 Canada

264. Richard Feely, National Oceanic \& Atmospheric Administration, Pacific Marine Envir. Lab, 7600 Sand Point Way, NE, Seattle, WA 98115

265. Gene C. Feldman, NASA/GSFC, Code 936, Building 28, Room W161B, Goddard Space Flight Center, Greenbelt, MD 20771

266. J. Filson, National Earthquake Information Center, U.S. Geological Survey, Denver Federal Center, P.O. Box 20546, Denver, CO 80225

267. Martin Q. Fleisher, Dept. of Geochemistry, Lamont-Doherty Earth Observatory, Columbia University, Palisades, NY 10964

268. Jerry F. Franklin, Bloedel Professor of Ecosystem Analysis, College of Forest Resources, University of Washington, Anderson Hall (AR-10), Seattle, WA 98195 
269. Diana W. Freckman, Director, College of Natural Resources, 101 Natural Resources Building, Colorado State University, Fort Collins, CO 80523

270. Richard H. Gammon, University of Washington, Chemistry Department, BG-10, Seattle, WA 98195

271. Wilford D. Gardner, Department of Oceanography, Texas A \& M University, College Station, TX 77843

272. Christopher Garside, Bigelow Laboratory for Ocean Science, McKnown Point, West Boothbay Harbor, ME 04575

273. Jean-Pierre Gattuso, Observatoire Oceanologique European, Avenue Saint-Martin, MC98000 , Monaco

274. Bob Gershey, Bedford Institute of Oceanography, Box 10061 Challenger Drive/Shannon Park, Dartmouth, Nova Scotia, Canada B2Y 4A2

275. Jorunn S. Gislefoss, Radiological Dating Laboratory, The Norwegian Institute of Technology, N-7034 Trondheim-NTH, Norway

276. John G. Goddard, Lamont-Doherty Earth Observatory of Columbia University, ClimateEnviornment/Ocean Division, RT 9W, Palisades, NY 10964-8000

277. Lars G. Golmen, Norwegian Institute for Water Research, Regional Office, Bergen, Thormohlensgt. 55 5008, Bergen, Norway

278. Catherine Goyet, Chemistry Dept., Woods Hole Oceanographic Institution, Clark 461, Woods Hole, MA 02543

279. S. Graves, National Aeronautics and Space Administration Headquarters Code SED, 600 Independence Avenue, Washington, DC 20546

280. J. L. Green, National Space Science Data Center, NASA Goddard Space Flight Center, Code 630.2, Greenbelt, MD 20771

281. Elizabeth Gross, SCOR, Department of Earth and Planetary Sciences, The John Hopkins University, Baltimore, MD 21218

282. Nicolas Gruber, Climate and Environmental Physics, Physics Insitute, University of Bern, Sidlerstr.5, CH-3012 Bern, Switzerland

283. Peter Guenther, Scripps Institution of Oceanography, University of California, Geological Research Div. 0220, 9500 Gilman Drive, La Jolla, CA 92093-0220

284. K. D. Hadeen, National Oceanic and Atmospheric Administration, NESDIS/NCDC, Federal Building MC E/CC, Asheville, NC 28801

285. Koh Harada, National Institute for Resources and Environment, 16-3 Onogawa, Tsukuba, Ibaraki 305, Japan 
286. Akira Harashima, National Institute for Environmental Studies, 16-2 Onogawa, Tsukuba, Ibaraki 305, Japan

287. R. C. Harriss, Institute for the Study of Earth, Oceans, and Space, Science and Engineering Research Building, University of New Hampshire, Durham, NH 03824

288. Mette Hein, Freshwater Biological Laboratory, Helsingoersgade 51, DK-3400 Hilleroed, Denmark

289. James C. Hendee, Data Manager, NOAA/AOML/OCD, 4301 Rickenbacker Causeway, Miami, FL 33149

290. W. J. Hinze, Purdue University, Department of Earth and Atmospheric Sciences, West Lafayette, IN 47907

291. Hilary Hodgson, DSC, Special Acquisitions, British Library, Boston Spa, Wetherby, West Yorkshire LS23 7BQ, United Kingdom

292. Huasheng Hong, Research Centre, The Hong Kong University of Science \& Technology, Clear Water Bay, Kowloon, Hong Kong

293. Masao Ishii, Meteorological Research Institute, 1-1 Nagamine, Tsukuba, Ibaraki, 305, Japan

294. John Jamerlan, Customer and Applications Support Technician, Europa Scientific,1776 Mentor Avenue, Cincinnati, OH 45212-3597

295-299. Kenneth M. Johnson, Brookhaven National Laboratory, OASD Bldg. 318, Upton, NY 11973

300. W. Keith Johnson, Centre For Ocean Climate Chemistry, Institute of Ocean Sciences, 9860 W. Saanich Road, Sidney, BC, Canada V8L 4B2

301. Fortunat Joos, Physics Institute, KUP, Sidlerstr. 5, CH-3012 Bern, Switzerland

302. G. Y. Jordy, Director, Office of Program Analysis, Office of Energy Research, ER-30, G-226, U.S. Department of Energy, Washington, DC 20585

303. Terrence M. Joyce, WOCE Hydrographic Program Office, Woods Hole Oceanographic Institution, Woods Hole, MA 02543

304. Susan Kadar, Clark 461, Woods Hole Oceanographic Institution, Woods Hole, MA 02543

305. Dong-Jin Kang, Marine Natural Products Chemistry Laboratory, Ansan P.O. Box 29, Seoul 425-600, Korea

306. David Karl, Department of Oceanography, University of Hawaii, 1000 Pope Road, Honolulu, HI 96822

307. Charles D. Keeling, Scripps Institution of Oceanography, University of California San Diego, Geological Research Division, A020, 2314 Ritter Hall, La Jolla, CA 92093-0220 
308. Kimberly C. Kelly, PMEL/NOAA, 7600 Sandpoint Way NE, Building 3, Seattle, WA 98115

309. Stephan Kemp, Geologisch-Palaontologisches Institut, H Darmstadt, Schnittspahnstrabe 9, 64287 Darmstadt, Gemany

310. Robert Key, Princeton University, Geology Department, Princeton, NY 08544

311. Kyung-Ryul Kim, Ph.D., Department of Oceanology, Seoul National University, Seoul $151-742$, Korea

312. Takashi Kimoto, Research Institute of Oceano-Chemistry, Osaka Office - 5-19 Funahashicho, Tennoji-ku, Osaka 543, Japan

313. Bert Klein, GIROQ Universite, Laval Pav., Vachon, Quebec PQ, Canada G1K 7P4

314. Anthony H. Knap, BBSR, Inc., Ferry Reach 1-15, Bermuda

315. S. Krishnaswami, Physical Research Laboratory, Navrangpura, Ahmedabad-380009, India

316. D. Lauer, EROS Data Center, U.S. Geological Survey, Sioux Falls, SD 57198

317. Dr. Nathalie Lefevre, Plymouth Marine Laboratory, Prospect Place, West Hoe, Plymouth PL1 3DH, United Kingdom

318. Margaret Leinen, Graduate School of Oceanography, University of Rhode Island, Kingston, RI 02882-1197

319. S. Levitus, NOAA/National Oceanographic Data Center, 1825 Connecticut Avenue, NW, Washington, DC 20235

320. Ernie Lewis, Oceanographic Sciences Division, Brookhaven National Laboratory, Upton, NY 11973

321. Marlon Lewis, Department of Oceanography, Dalhousie University, Halifax, Nova Scotia B3H 4J1, Canada

322. A. M. Linn, Program Officer, BESR, National Academy of Sciences, Harris Building 372, 2101 Constitution Avenue NW, Washington, DC 20418

323. Hugh D. Livingston, Woods Hole Oceanographic Institution, Clark 4, Woods Hole, MA 02543

324. M. S. Loughridge, National Oceanic and Atmospheric Administration, National Geophysical Data Center, Code E/GC3, 325 Broadway, Boulder, CO 80303

325. Clarence Low, NASA-Ames Research Center, Mail Stop 239-4, Moffett Field, CA 94035-1000

326. Bram Majoor, Netherlands Institute for Sea Research, P.O. Box 59, 1790 Ab den Burg, Texel, The Netherlands 
327. James J. McCarthy, Museum of Comparative Zoology, Harvard University, 26 Oxford Street, Cambridge, MA 02139

328. Dennis McGillicuddy, Physical Oceanography Department, Woods Hole Oceanographic Institution, Clark 205A, Woods Hole, MA 02543

329. Nicolas Metzl, Universite Pierre et Marie Curie - Paris 6, Laboratoire de Physique et Chimie Marines, T24-25 - Case 134-4, place Jussieu-75252, Cedex 05, France

330. Frank J. Millero, University of Miami, RSMAS, 4600 Rickenbacker Causeway, Miami, FL 33149-1098

331. DongHa Min, Trace Gas Lab, Department of Oceanography, Seoul National University, Seoul, Korea (151-742)

332-336. Dr. Ludger Mintrop, Marine Chemist, Institute for Marine Research, Marine Chemistry Department, Duesternbrooker Weg 20, D-214105 Kiel, Germany

337. M. Nicole Momzikoff, Bibliothecaire, Institut Oceanographique Bibliotheque, 195, rue Saint-Jacques, F 75005 Paris, France

338. Pedro M. S. Monteiro, Department of Oceanography, University of Cape Town, Rondebosch 7700 , South Africa

339. Lloyd Moore, NOAA/AOML/OCD, 4301 Rickenbacker Causeway, Miami, FL 33149

340. Mary Morris, The Martin Ryan Marine Science Institute, University College, Galway, Ireland

341. John W. Morse, Department of Oceanography, Texas A \& M University, College Station, TX 77843-3148

342. Peter J. Muller, Universitat Bremen, Fachbereich Geowissenschaften, Postfach 330 440, D-28334 Bremen, Germany

343. Shohei Murayama, Atmospheric Environment Division, National Institute for Resources and Environment, 16-3 Onogawa, Tsukuba, Ibaraki 305 Japan

344. Paulette P. Murphy, PMEL/NOAA, 7600 Sandpoint Way NE, Building 3, Seattle, WA 98115

345. James W. Murray, School of Oceanography, WB-10, University of Washington, Seattle, WA 98195

346. Jae Ryoung Oh, Chemical Oceanography lab, KORDI, An San P.O. Box 29, Seoul 425600 , Korea

347. Eiji Ohtaki, Environmental Science and Technology, Okayama University, Okayama 700, Japan

348. Jon 'Olafsson, Marine Research Institute, P.O. Box 1390, Skulagata 4, 121 Reykjavik, Iceland 
349. Curtis R. Olsen, US Department of Energy, Environmental Sciences Division, ER-74, Office of Energy Research, 19901 Germantown Road, Germantown, MD 20874-1290

350. R. H. Olsen, Vice President for Research, University of Michigan, Medical Science Building II, \#5605, 1301 East Catherine Street, Ann Arbor, MI 48109-0620

351. Michael J. Orren, Professor, Head. Dept. Of Oceanography, Universtiy College Galway, 80 Harcourt Street, Dublin 2, Ireland

352. Claude Oudot, Centre ORSTOM de Cayenne, B. P. 165-97323, CAYENNE Cedex, French Guyana

353. J. T. Overpeck, National Oceanic and Atmospheric Administration, National Geophysical Data Center, Paleoclimatology Program, 325 Broadway E/EC, Boulder, CO 80303

354. Bobbi Parra, US Department of Energy, Environmental Sciences Division, Office of Health and Environmental Research, 19901 Germantown Road, Germantown, MD 208741290

355. Ari Patrinos, Associate Director, Office of Health and Environmental Research, U.S. Department of Energy, 19901 Germantown Road, Germantown, MD 20874-1290

356. Kay Pegler, Universitat Hamburg, Institut fur Biogeochemie und Meereschemie, Jungiusstrasse, 6, 1000 Hamburg 36, Germany

357. T-H Peng, Ocean Chemistry Division, NOAA/AOML/OCD, 4301 Rickenbacker Causeway, Miami, FL 33149

358. Dr. Fiz F. Perez, Consejo Superior de Investigaciones Cientificas, Instituto de Investigacions Marinas, Eduardo Cabello, 6-36208 VIGO (Espana)

359. Trevor Platt, Department of Fisheries \& Oceans, Bedford Institute of Oceanography, P.O. Box 1006, Dartmouth, Nova Scotia B2Y 4A2, Canada

360. Alain R. H. Poisson, Univ. Pierre et Marie Cuie, Lab de Phys. et Chimie Marines, Case 134, 4 Place Jussieu, 75252 Paris Cedex 05, France

361. Barbara Preselin, Dept. of Biological Sciences, University of California, Santa Barbara, CA 93106

362. Paul Quay, School of Oceanography, WB-10, University of Washington, Seattle, WA 98195

363. S. Ichtiaque Rasool, IGBP Data and Information System Office, Universite Paris, Tour 26, 4 Etage, Aile 26-16, 4 Place Jussieu, 75230 Paris, Cedex 06, France

364. Clare Reimers, Institute of Marine and Coastal Sciences, Rutgers University, P.O. Box 231, New Brunswick, NJ 08903-0231

365. Joachim Ribbe, Flinders University of S. A., School of Earth Sciences, GPO Box 2100, Adelaide, 5001 S. A., Australia 
366. Michael R. Riches, Environmental Sciences Division, Office of Health and Environmental Research, ER-74, U.S. Department of Energy, 19901 Germantown Road, Germantown, MD 20874-1290

367. Aida F. Rios, Consejo Superior de Investigaciones Cientifican, Instituto de Investigacions Marinas, Eduardo Caballo 6-36208, Vigo, Spain

368. Marilyn Roberts, NOAA/PMEL, 7600 Sandpoint Way NE, Building 3, Seattle, WA 98115

369. Jane Robertson, University of Wales, Department of Geology, P.O. Box 914, Cardiff CF1 3YE, United Kingdom

370. Carol Robinson, University of Wales: Bangor, School of Ocean Sciences, Menai Bridge, Gwynedd LL59 5EY, United Kingdom

371. Stephany Rubin, Lamont-Doherty Earth Observatory of Columbia University, Ulimate/Environment/Ocean Division, RT 9W, Palisades, NY 10964-8000

372. Christopher Sabine, Princeton University, Geology Dept./Guyot Hall, Princeton, NJ 08544

373. Dan Sadler, Univerrsity of Hawaii, 1000 Pope Road, Honolulu, HI 96822

374. Ray Sambrotto, Lamont-Doherty Earth Observatory, Columbia University, P.O. Box 1000, Palisades, NY 10964

375. Jorge L. Sarmiento, Universitat Bern, Physikalisches Institut, Abteilung KUP, Sidlerstrasse 5, 3012 Bern, Switzerland

376. Tatyana G. Sazhina, P. Shirshov Institute of Oceanology, Russian Academy of Sciences, 23, Krasikova Str., Moscow 117218 Russia

377. Claire L. Schelske, 'Department of Fisheries and Aquaculture, University of Florida, 7922 W 71st Street, Gainesville, FL 32606

378-382. Bernd Schneider, Institut fur Ostseeforschung, SeestraBe 15, Rostock-Warnemunde, Germany

383. Alan Shiller, Center for Marine Science, University of Southern Mississippi, Stennis Space Center, MS 39529

384. Kiminori Shitashima, Environmental Science Department, Abiko Research Laboratory, Central Research Institute of Electric Power Industry, 1646, Abiko, Abiko City, Chiba, 270-11, Japan

385. A. L. Shumbera, National Oceanic and Atmospheric Administration, WDC-A for Meteorology, National Climatic Data Center, Federal Building MC E/CC, Asheville, NC 28801

386. Nelson Silva, Escuela de Ciencias del Mar, Universidad Catolica de Valparaiso, Casilla 1020, Valparaiso, Chile 
387. Sharon Smith, RSMAS, University of Miami, 4600 Rickenbacker Causeway, Miami, FL 33149

388. Michel H. C. Stoll, Centre for Environmental and Resources Studies, Hoeyteknologisenteret University of Bergen, N-5020 Bergen, Norway

389. Eric T. Sundquist, U.S. Geological Survey, Branch of Atlantic Marine Geology, Quissett Campus, Woods Hole, MA 02543

390. Stewart C. Sutherland, Lamont-Doherty Earth Observatory of Columbia University, Climate/Environment/Ocean Division, RT 9W, Palisades, NY 10964-8000

391. James H. Swift, Scripps Institution of Oceanography, University of California, San Diego Oceanographic Data Facility, 9500 Gilman Drive, La Jolla, CA 92093-0124

392. Taro Takahashi, Lamont-Doherty Earth Observatory of Columbia University, Climate/Environment/Ocean Division, RT 9W, Palisades, NY 10964-8000

393. Lynne D. Talley, Scripps Institution of Oceanography, UCSD 0230, 9500 Gilman Drive, La Jolla, CA 92075-0230

394. James F. Todd, NOAA/OAR Office of Global Programs, Room 4142, SSMC-1, 1335 East-West Highway, Silver Spring, MD 20910

395. Jane Tucker, Marine Biological Laboratory, Woods Hole, MA 02543

396. David Turner, Department of Analytical and Marine Chemistry, University of Goteborg, S-41296 Goteborg, Sweden

397. J. Val Klump, Center for Great Lakes Studies, University of Wisconsin, 600 East Greenfield Avenue, Milwaukee, WI 53204

398. Michiel Rutgers van der Loeff, Alfred Wwegener Institute for Polar and Marine Research, Columbusstrasse 2855, Bremerhaven, Germany

399-403. Douglas W. R. Wallace, Brookhaven National Laboratory, Oceanographic Sciences Division, Bldg. 318, Upton, NY 11973

404. Richard H. Wanninkhof, NOAA/AOML/OCD, 4301 Rickenbacker Causeway, Miami, FL 33149

405. Bess B. Ward, Marine Sciences Program, University of California, Santa Cruz, CA 95064

406. Richard Weisburd, National Institute for Environmental Studies, 16-2 Onogawa, Tsukuba, Ibaraki, 305, Japan

407. Ray F. Weiss, University of California, Scripps Institute of Oceanography, Mail code A020, Room 2271, Ritter Hall, La Jolla, CA 92093

408. Richard J. Wilke, Brookhaven National Laboratory, Oceanographic Sciences Division, Bldg. 318, Upton, NY 11973 
409. Christopher Winn, Scripps Institution of Oceanography, Marine Physical Lab, 9500 Gilman Drive, La Jolla, CA 92093-0230

410. Amos Winter, Ph.D., Associate Professor, Marine Geology, University of Puetro Rico, Department of Marine Sciences, Mayaguez, Puerto Rico 00681-5000

411. F. J. Wobber, Environmental Sciences Division, Office of Health and Environmental Research, Office of Energy Research, ER-74, U.S. Department of Energy, 19901 Germantown Road, Germantown, MD 20874-1290

412. C. S. Wong, Centre for Ocean Climate Chemistry, Institute of Ocean Sciences, P.O. Box 6000 , Sidney, British Columbia V8L 4B2, Canada

413. L. Xu, Department of Oceanography, Xiamen University, Xiamen, Fujian, Peoples Republic of China

414. Evgeniy V. Yakushev, Ph.D., Senior Associate Scientist, P. P. Shirshov Institute of Oceanology, Russian Academy of Sciences, 26 Krasikova Street, 109017 Moscow, Russia

415. Masumi Yamamuro, Marine Geology Department, Geological Survey of Japan, 1-1-3 Higashi, Tsukuba, Ibaraki 305, Japan

416. D. B. Yang, Korea Ocean Research and Development Institute, Ansan, P.O. Box 29, Seoul, 425-600, Korea

417. Office of Assistant Manager for Energy Research and Development, U.S. Department of Energy Oak Ridge Operations, P. O. Box 2001, Oak Ridge, TN 37831-8600

418-419. Office of Scientific and Technical Information, P. O. Box 62, Oak Ridge, TN 37831 
